\title{
Increasing soil carbon storage: mechanisms, effects of agricultural practices and proxies. A review
}

\author{
Marie-France Dignac $^{1}$ (D) Delphine Derrien ${ }^{2} \cdot$ Pierre Barré $^{3} \cdot$ Sébastien Barot $^{4}$. \\ Lauric Cécillon ${ }^{5}$. Claire Chenu ${ }^{1}$ - Tiphaine Chevallier ${ }^{6}$. Grégoire T Freschet $^{7}$. \\ Patricia Garnier $^{1}$ - Bertrand Guenet ${ }^{8}$ - Mickaël Hedde ${ }^{1}$ - Katja Klumpp ${ }^{9}$. \\ Gwenaëlle Lashermes $^{10}$ • Pierre-Alain Maron ${ }^{11}$ • Naoise Nunan ${ }^{4}$. Catherine Roumet ${ }^{7}$. \\ Isabelle Basile-Doelsch ${ }^{12}$
}

Accepted: 9 March 2017 / Published online: 7 April 2017

(C) INRA and Springer-Verlag France 2017

\begin{abstract}
The international 4 per 1000 initiative aims at supporting states and non-governmental stakeholders in their efforts towards a better management of soil carbon (C) stocks. These stocks depend on soil $\mathrm{C}$ inputs and outputs. They are the result of fine spatial scale interconnected mechanisms, which stabilise/destabilise organic matter-borne C. Since 2016, the CarboSMS consortium federates French researchers working on these mechanisms and their effects on $\mathrm{C}$ stocks in a local and global change setting (land use, agricultural practices, climatic and soil conditions, etc.). This article is a synthesis of this consortium's first seminar. In the first part, we
\end{abstract}

This synthesis of the CarboSMS French consortium's first seminar was already published in French: Derrien D, Dignac M-F, Basile-Doelsch I, Barot S, Cécillon L, Chenu C, Chevallier T, Freschet GT, Garnier P, Guenet B, Hedde M, Klumpp K, Lashermes G, Maron P-A, Nunan N, Roumet C, Barré P (2016) Stocker du C dans les sols: Quels mécanismes, quelles pratiques agricoles, quels indicateurs? Etude et Gestion des Sols 23:193-223.

We prepared this English version in accordance with Dr. Dominique Arrouays, chief editor of Etude et Gestion des Sols.

Marie-France Dignac

marie-france.dignac@inra.fr

1 UMR ECOSYS, INRA, AgroParisTech, Université Paris-Saclay, F-78850 Thiverval-Grignon, France

2 Biogéochimie des Ecosystèmes Forestiers, INRA, F-54280 Champenoux, France

3 Laboratoire de Géologie de l'ENS, PSL Research University, UMR 8538 of CNRS, 24 rue Lhomond, F-75231, cedex 05 Paris, France

4 UMR iEES-Paris (CNRS, UPMC, INRA, IRD), 4 place Jussieu, F-75005 Paris, France

5 Université Grenoble Alpes, Irstea, UR EMGR, 2 rue de la Papeterie-BP 76, F-38402 St-Martin-d'Hères, France present recent advances in the understanding of soil $\mathrm{C}$ stabilisation mechanisms comprising biotic and abiotic processes, which occur concomitantly and interact. Soil organic $\mathrm{C}$ stocks are altered by biotic activities of plants (the main source of $\mathrm{C}$ through litter and root systems), microorganisms (fungi and bacteria) and 'ecosystem engineers' (earthworms, termites, ants). In the meantime, abiotic processes related to the soil-physical structure, porosity and mineral fraction also modify these stocks. In the second part, we show how agricultural practices affect soil C stocks. By acting on both biotic and abiotic mechanisms, land use and management practices

6 Eco\&Sols (IRD, Montpellier SupAgro, Cirad, INRA), Campus SupAgro, Bldg 12, F-34060 Montpellier, France

7 Centre d'Ecologie Fonctionnelle et Evolutive, UMR 5175 (CNRS, Université de Montpellier, Université Paul-Valéry Montpellier, EPHE), 1919 route de Mende, F-34293 Montpellier, France

8 Laboratoire des Sciences du Climat et de l'Environnement (LSCE/IPSL, CEA, CNRS, UVSQ, Université Paris-Saclay), F-91191 Gif-sur-Yvette, France

9 INRA, UREP, F-63039 Clermont-Ferrand, France

10 UMR FARE (INRA, URCA), F-51100 Reims, France

11 Agroécologie, AgroSup Dijon, INRA, University Bourgogne Franche-Comté, F-21000 Dijon, France

12 Aix-Marseille Université, CNRS, IRD, Coll France, INRA, CEREGE, F-13545 Aix-en-Provence, France 
(choice of plant species and density, plant residue exports, amendments, fertilisation, tillage, etc.) drive soil spatiotemporal organic inputs and organic matter sensitivity to mineralisation. Interaction between the different mechanisms and their effects on $\mathrm{C}$ stocks are revealed by meta-analyses and long-term field studies. The third part addresses upscaling issues. This is a cause for major concern since soil organic $\mathrm{C}$ stabilisation mechanisms are most often studied at fine spatial scales $(\mathrm{mm}-\mu \mathrm{m})$ under controlled conditions, while agricultural practices are implemented at the plot scale. We discuss some proxies and models describing specific mechanisms and their action in different soil and climatic contexts and show how they should be taken into account in large scale models, to improve change predictions in soil C stocks. Finally, this literature review highlights some future research prospects geared towards preserving or even increasing $\mathrm{C}$ stocks, our focus being put on the mechanisms, the effects of agricultural practices on them and $\mathrm{C}$ stock prediction models.

Keywords Soil organic $\mathrm{C} \cdot \mathrm{C}$ dynamics $\cdot$ Stabilisation mechanisms $\cdot$ Mineralisation $\cdot$ Agricultural practices . Indicators $\cdot$ Models $\cdot$ Macrofauna $\cdot$ Microorganisms $\cdot$ Litter $\cdot$ Root inputs · Organomineral associations $\cdot$ Porosity

\section{Contents}

1. Introduction

2. Soil C storage mechanisms: state of the art

2.1. Action of living biomass on soil organic $\mathrm{C}$ dynamics

2.1.1. Plants, rhizosphere and soil organic $\mathrm{C}$ storage - importance of root systems

2.1.2. Impact of living organisms on soil $\mathrm{C}$ sequestration - the macrofauna case

2.1.3. Diversity and physiology of microorganisms - drivers of soil C dynamics

2.2. Abiotic soil organic $\mathrm{C}$ stabilisation mechanisms

2.2.1. Localisation in the physical structure of soil

2.2.2. C stabilisation mechanisms involving organomineral interactions

3. Mechanisms of OM dynamics affected by agricultural practices

3.1. Review of the main agricultural practices

3.2. Impact of agricultural practises on soil organic $\mathrm{C}$ storage

4. How could a better accounting of OM stabilisation mechanisms improve the prediction of soil organic $\mathrm{C}$ stock evolution?

4.1. Finding indicators to improve prediction of changes in soil organic $\mathrm{C}$ stocks

4.2. Better integration of $\mathrm{OM}$ stabilisation mechanisms in large-scale $\mathrm{C}$ dynamics models
4.3. Modelling OM mineralisation at the micro-scale could help in describing macroscopic $\mathrm{C}$ fluxes

4.4. Data needed to constrain various approaches to enhance prediction of soil $\mathrm{C}$ stock evolution patterns

5. Conclusion

Acknowledgments

References

\section{Introduction}

The increasing atmospheric concentration of greenhouse gases (GHG), particularly those containing carbon $\left(\mathrm{CO}_{2}, \mathrm{CH}_{4}\right)$, is a consequence of human activities and is associated with climate change. Anthropogenic carbon emissions are partially balanced by carbon (C) sinks in oceans, vegetation and soil (Le Quéré et al. 2015). Soils contain approximately three times more $\mathrm{C}$ than the atmosphere (2400 vs. $800 \mathrm{GtC})$ (Jobbágy and Jackson 2000), in the form of organic C borne in organic matter $(\mathrm{OM})$. On decadal time scales, soils can serve as a $\mathrm{C}$ sink or source depending on their properties, on the climate, land use, etc. (Eglin et al. 2010).

Global models linking the atmospheric $\mathrm{CO}_{2}$ concentration to temperature show that a $3.5-4 \mathrm{Gt} / \mathrm{year}$ decrease in atmospheric $\mathrm{C}$ would limit the temperature increase to $+1.5 / 2{ }^{\circ} \mathrm{C}$ by 2050 (Meinshausen et al. 2009; Minasny et al. 2017), i.e. the threshold beyond which climate change would have a significant impact (IPCC 2013). This annual decrease in the atmospheric $\mathrm{CO}_{2}$ concentration could be fulfilled by annually increasing $\mathrm{C}$ stocks in the top $30 \mathrm{~cm}$ soil horizon by $0.4 \%$ (4 per 1000) (Balesdent and Arrouays 1999; Paustian et al. 2016).

In this context, the 4 per 1000 - Carbon Sequestration in Soils for Food Security and the Climate initiative, launched by France in 2015 ahead of COP21 in Paris (http://4p1000.org/), aims to bring together governmental and non-governmental stakeholders devoted to improving soil $\mathrm{C}$ stock management. Positive effects on food security and climate change are expected through the collective objective of increasing $\mathrm{C}$ stocks on a global scale in agricultural areas (croplands, grasslands, forests), on which human action can be oriented towards $\mathrm{C}$ storage (Paustian et al. 2016). Indeed, increasing soil OM stocks is also beneficial for soil fertility, since OM mineralisation might be a source of nutriments for plants. But this requires implementing agricultural practices adapted to local conditions that will increase soil $\mathrm{C}$ inputs, with outputs remaining stable or decreasing, thus maximising soil $\mathrm{C}$ storage.

Soil OM is not homogeneous, and some OM is quickly mineralised after entering the soil, while some persists for very long periods (Schmidt et al. 2011). Conceptual pools were sometimes associated to functional pools tentatively separated from soils according to chemical or physical fractionation 
(e.g. Balesdent 1996; Zimmermann et al. 2007; Crow et al. 2007; Moni et al. 2012). In recent years, the significance of the chemical fractions obtained after the so-called humic substances separation have been questioned since they are probably artefacts formed during the drastic chemical extraction treatment (Schmidt et al. 2011). Reconciliating conceptual and experimental pools of soil $\mathrm{C}$ with different dynamics is still a matter of research, especially when soil organic matter is now accepted as a continuum of organic molecules possibly associated with minerals (Lehmann and Kleber 2015).

Three soil conceptual $\mathrm{C}$ pools are generally defined according to their degradation rate (Fig. 1) (von Lützow et al. 2008). Labile OM turnover occurs within a day to a year. OM turnover in the intermediate pool occurs within a few years to decades. Both pools originate predominantly from plant, animal, bacterial and fungal residues. The intermediate pool is also supplied by OM degradation products from the labile pool. This OM pool is rather active with rather fast turnover, so it is highly influenced by soil management practices. Finally, the turnover of the stable OM pool occurs on time scales ranging from decades to centuries. It originates from labile and intermediate pools and involves most of the soil organic C (Torn et al. 2009). It consists of plant, animal, bacterial or fungal residues and microbial metabolic products. $\mathrm{OM}$ in the stable pool can be found in aggregates and/or adsorbed on mineral surfaces.

The challenge for the 4 per 1000 initiative is to increase the size of the intermediate and stable $\mathrm{C}$ pools in order to maximise the sustainability of additional $\mathrm{C}$ storage, i.e. maximising the residence time of this additional $\mathrm{C}$ in soil. $\mathrm{C}$ storage/ release in these reservoirs is driven by biotic and abiotic mechanisms that operate at fine spatial scales within the soil organomineral matrix. It is essential to understand these mechanisms and interactions so as to be able to anticipate and control changes in soil $\mathrm{C}$ contents in an ever-evolving environment (changes in land use, agricultural practices, climatic

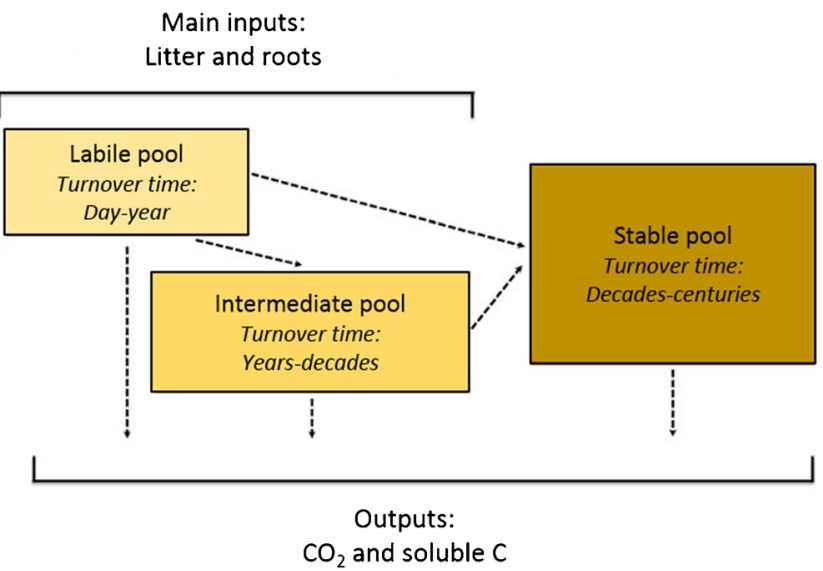

Fig. 1 Conceptual pools of soil $\mathrm{C}$ depending on its turnover time: labile, intermediate and stable pools or edaphic conditions, etc.). Many research groups are addressing these scientific challenges while striving to overcome scientific knowledge gaps on these mechanisms. However, it is hard to compare this information on various spatiotemporal scales, which has led to the creation of a national research network in France (to be expanded internationally) to federate the strengths of our scientific community on this issue.

The CarboSMS (Carbon Stabilization Mechanisms in Soil) research network was launched in late 2015 and currently consists of about 110 members. Some 70 researchers attended the CarboSMS kickoff meeting at the Ecole Normale Supérieure (ENS) in Paris on 10 March 2016. The present article summarises the outcome of this meeting. In the first part, we present recent advances on the mechanisms involved in soil organic $\mathrm{C}$ sequestration and then discuss the effects of agricultural practices on these mechanisms in the second part. Finally, in the third part, we show how it is essential to account for these mechanisms in global models and define indicators to describe $\mathrm{C}$ dynamics in order to enhance the prediction of the patterns of change of soil organic $\mathrm{C}$ stocks.

\section{Soil C storage mechanisms: state of the art}

Two main types of mechanisms influence the stabilisation/ destabilisation of soil organic $\mathrm{C}$ : biotic mechanisms related to living soil biomass and soil biodiversity (plants, fauna, microorganisms) and abiotic mechanisms (localisation in the soil physical structure and degradation/stabilisation hotspots, organomineral interactions). For the sake of clarity, these mechanisms will be discussed successively in the following section, although they occur simultaneously in soils, combining or neutralising their effects.

\subsection{Action of living biomass on soil organic C dynamics}

\subsubsection{Plants, rhizosphere and soil organic $C$ storage-importance of root systems}

The effects of plants on soil OM are twofold. First, as autotrophic organisms, plants are the main source of soil organic $\mathrm{C}$ through their litter production (shoots and roots), root exudates (released through passive and active mechanisms) and via symbiotic (nitrogen-fixing and mycorrhizal) associations. Second, plants contribute to soil OM stabilisation mechanisms by producing poorly degradable compounds and by promoting stable aggregate formation. By limiting erosion, plants also contribute to soil OM conservation.

Plants have a broad range of root systems and their influence on soil OM varies with the plant species and root functional traits (i.e. architecture, morphology, physiology, chemical composition and symbiotic associations, Fig. 2). 


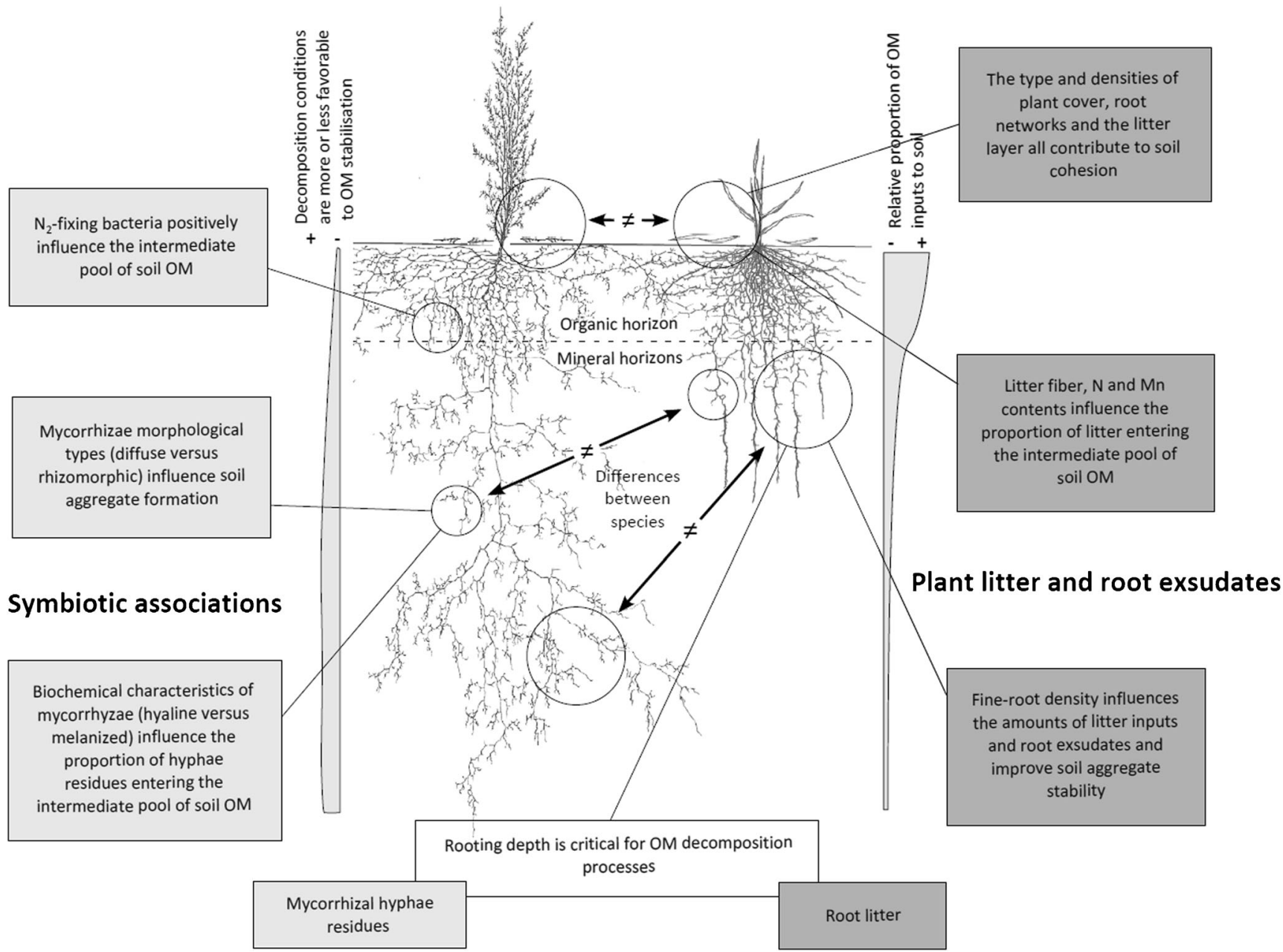

Fig. 2 Differences in functional traits and symbiotic associations between different plant species influence soil organic matter stabilisation. Adapted from Freschet et al. (in press)

OM fluxes from plants to soils $\mathrm{C}$ inputs to the soil consist of above- and belowground litter (leaves, branches, stem, roots...), but also of rhizodeposits and of compounds that are directly transferred to mycorrhizal fungi. Root litter contributes about one third of total litter inputs in grassland soils and half in forest soils (Freschet et al. 2013). Rhizodeposition represents about $11 \%$ of the $\mathrm{C}$ assimilated by plants or $27 \%$ of that allocated to roots (Jones et al. 2009; Balesdent et al. 2011). The type and intensity of mycorrhizal associations, and therefore of $\mathrm{C}$ transfers to mycelial hyphae, depend respectively on the plant phylogenetic identity and on soil factors, especially on the availability of soil nutrients (Soudzilovskaia et al. 2015).

Some recent and debated studies suggest that belowground inputs largely contribute to OM, which is stabilised in soils on the medium to long term (Balesdent and Balabane 1996; Kuzyakov and Domanski 2000; Mendez-Millan et al. 2010; Clemmensen et al. 2015), especially in deeper soil horizons (Rasse et al. 2005; Rumpel and Kögel-Knabner 2011; Mendez-Millan et al. 2012). In particular, the study by
Jobbágy and Jackson (2000) showed that the vertical root distribution corresponds to that of soil organic $\mathrm{C}$ for different plant species and soil types. Indeed, root litter decomposition is generally $30 \%$ slower than leaf decomposition (Birouste et al. 2012; Freschet et al. 2013). In addition, aboveground litter inputs are only partly transferred into the mineral soil (Garten 2009), where the decomposition rate decreases with increasing depth (Garcia-Pausas et al. 2012; Poirier et al. 2014; Prieto et al. 2016).

The contribution of belowground input to $\mathrm{C}$ storage occurs through the persistence of plant residues or via the stimulation of soil microbial activity and the increase of the contribution of microbial necromass to the slow cycling soil OM pools (Beniston et al. 2014; DuPont et al. 2014; Lange et al. 2015; Morriën et al. 2017).

The architecture and rooting profile of species are thus critical traits that control the amount and location of $\mathrm{C}$ inputs in the soil profile. Amongst herbaceous plants, monocots generally produce greater root biomass than forbs (Poorter et al. 2015) and have higher fine root densities (Craine et al. 2003), 
suggesting larger C inputs to soil. Lange et al. (2015) also demonstrated that higher plant diversity increases rhizosphere carbon inputs.

Quality of OM inputs and impact on their decomposition rate The chemical composition [e.g. concentration in $\mathrm{C}$, lignins, nitrogen $(\mathrm{N})$ and manganese $(\mathrm{Mn})$ ] of aboveground and belowground litter inputs and root exudates varies markedly between plant species and influences $\mathrm{OM}$ decomposition kinetics on time scales ranging from year to decade (Jones et al. 2009; Machinet et al. 2011; Birouste et al. 2012). It is commonly recognised that a high lignin content leads to the accumulation of particulate $\mathrm{OM}$ in the soil (Cotrufo et al. 2015) and increases the plant residue contribution to the intermediate OM pool (Fig. 1). The litter Mn content stimulates lignin degradation through the formation of Mn peroxidases involved in lignin oxidation (Berg 2014; Keiluweit et al. 2015a). High $\mathrm{N}$ levels in plant litter and residues generally increase their initial decomposition rate, and result in the accumulation of microbial residues that persist in the soil. At the same time, high $\mathrm{N}$ levels in plant residues inhibit the specific decomposition of lignins (Berg et al. 2010; Dignac et al. 2002; Martins and Angers 2015), probably due to the recombination of $\mathrm{N}$ with partially decomposed lignin molecules (Berg et al. 2010).

The type and intensity of mycorrhizal associations strongly influence the OM fate in soils (Fig. 2) (Clemmensen et al. 2013, 2015). Roots colonised by ectomycorrhiza, as well as mycelial hyphae from both ecto- and endomycorrhiza, decompose more slowly than non-mycorrhizal roots (Langley et al. 2006). Moreover, mycorrhizal hyphae differ in their morphological (diffuse vs. rhizomorphic) and biochemical (hyaline vs. melanised) characteristics (Fernandez and Kennedy 2015). Melanised compounds could be involved in fungal OM persistence in soils (Fernandez et al. 2016). Several recent studies suggest that the chemical composition of OM inputs may not explain their persistence in soils beyond a decade, but has an impact on the $\mathrm{C}$ pool cycling over year to decade. Over longer time scales, this persistence would depend more on environmental conditions (Amelung et al. 2008; Derrien et al. 2006; Thevenot et al. 2010; Schmidt et al. 2011; Andreetta et al. 2013; Lehmann and Kleber 2015; Mathieu et al. 2015).

\section{Impact of plant residue inputs on soil OM degradation} (priming effect) Fresh OM inputs that are easily used by soil microbial decomposers, such as root exudates, leachates and the labile portion of litter, can also stimulate native soil OM degradation. This so-called priming effect can be explained by three potentially co-occurring mechanisms (Löhnis 1926; Fontaine et al. 2004, 2007; Blagodatskaya and Kuzyakov 2008): (1) increased activity and development of microbial communities specialised in acquiring labile resources ( $r$ strategists) resulting in increased soil enzymatic activities with potentially negative effects on soil OM storage; (2) stimulation of microbial communities adapted to the degradation of less degradable substrates (K-strategists), which depends on the nutrient availability in soils (Fontaine et al. 2011; Derrien et al. 2014); and (3) the action of root exudates (e.g. oxalic acid) disrupting soil organomineral associations and providing microorganisms with access to previously stabilised organic compounds (Keiluweit et al. 2015b).

Aggregate stability and soil layer cohesion Plants contribute to the formation of stable aggregates (OM protected from degradation, see Section 2.2.1 below) in soil through fine roots and mycorrhizal associations (Tisdall and Oades 1982). High fine root and mycelial hyphae densities improve aggregate stability (Fig. 2) (Wu et al. 2014; Erktan et al. 2016) through different mechanisms: (1) increased production of root exudates, such as polysaccharides, which act as a glue between soil particles, (2) better soil particle trapping facilitated by the entanglement of roots and hyphae, (3) increased wetting-drying cycle frequency in soil in relation to water acquisition by roots, (4) input of plant residues containing specific constituents (e.g. hemicellulose, suberin or phenolic compounds) that contribute to macroaggregate stability and (5) stimulation of the production of microbial metabolites involved in microaggregate stability (Martens 2000; von Lützow et al. 2008; Martins and Angers 2015). These processes vary between plant species, but also depend on mycorrhizal fungi (Rillig et al. 2015). Hyphae with a diffuse morphology, thus promoting soil-hyphal interactions, could therefore have a greater impact on soil aggregate formation than hyphae of rhizomorphic types (Fernandez and Kennedy 2015). Finally, polysaccharides secreted by $\mathrm{N}_{2}$-fixing bacteria also have a positive effect on soil aggregate formation (Martins and Angers 2015).

Vegetation also contributes indirectly to soil C storage/ release by affecting soil physical structure. The density and permanence of aboveground plant cover, as well as the plant's ability to accumulate litter, protect topsoil from structural breakdown under the action of rainfall (Fig. 2) (Le Bissonnais et al. 2005). Species with high root length density (e.g. monocot species) and high root branching intensity (e.g. annual species) within topsoil also limits surface erosion and water runoff by promoting soil particle trapping (Gyssels et al. 2005). High root length density and fast root turnover also promote the formation of galleries that increase the soil porosity and limit water runoff (Gyssels et al. 2005). However, this also increases soil moisture and may improve conditions for soil OM decomposition in deeper soil horizons. Finally, species with deep root systems, high root length density and high root branching intensity can improve the cohesion between soil layers and limit landslides (Stokes et al. 2009).

In conclusion, plants influence labile, intermediate and stable soil C pools. The effects of plants on soil OM stabilisation and protection seem to be mostly positive, although the balance between positive and negative effects (i.e. overmineralisation) will differ according to interactions between plants and the soil abiotic and biotic conditions. For instance, 
plant-microbe, plant-plant, plant-animal (herbivory-related) and plant-soil interactions and their effects on $\mathrm{C}$ stabilisation mechanisms have yet to be extensively explored. Furthermore, although chemical recalcitrance has been shown to have little influence on long-term soil $\mathrm{C}$ stabilisation (Marschner et al. 2008; Schmidt et al. 2011; Dungait et al. 2012), it may influence the intermediate $C$ pool (Fig. 1) and the secondary consumption/transformation of these OMs by macro- and microorganisms (Moorhead et al. 2014). The search for new indicators of $\mathrm{C}$ dynamics linked to the chemical composition of plant tissues could improve our knowledge on these mechanisms. In this context, another major challenge is to gain greater insight into the role of the functional diversity of plants and of their symbionts in soil OM stabilisation/destabilisation mechanisms. This challenge requires stronger interactions between soil science, plant and microbial ecology and the development of long-term comparative laboratory and field studies before testing the relevance of these mechanisms in models. To this aim, experimental platforms (e.g. Ecotrons) and stable isotope techniques to differentiate $\mathrm{C}$ fluxes would help to gain insight into how the spatial distribution of roots and their symbionts can influence OM stabilisation through mechanisms related to soil physical properties, as presented in the Section 2.2 of this review.

\subsubsection{Impact of living organisms on soil C sequestration - the macrofauna case}

The diversity of organisms hosted in soils is huge in terms of size and function, encompassing megafauna, macrofauna, microfauna and microorganisms. Soil macrofauna includes organisms larger than $2 \mathrm{~mm}$ with high taxonomic diversity, including millipedes (diplopoda and centipedes), woodlice, earthworms, some springtails, numerous spiders and insects (ants, beetles, termites), in addition to vertebrates such as rodents (mice) and insectivores (moles, shrews). Functionally, these animals can be grouped according to their diet (zoophagous, herbivorous, root-feeding, saprophagous, soilfeeding, etc.) or to their impact on their physical and chemical environment. The best known group includes 'ecosystem engineers' (earthworms, ants and termites). These organisms often represent a large biomass in soils (individually for earthworms or socially for termites and ants), having a substantial influence on soil OM dynamics (Chevallier et al. 2001) (Fig. 3).

Processes promoting $\mathbf{C}$ stabilization In tropical and temperate regions, it is widely recognised that long-term OM stabilisation is controlled by interactions between microorganisms (fungi and bacteria), ecosystem engineers (roots, earthworms, termites, ants) and the soil mineral matrix (Lavelle 1997). Ecosystem engineers act by fragmenting litter, incorporating it into the soil profile,

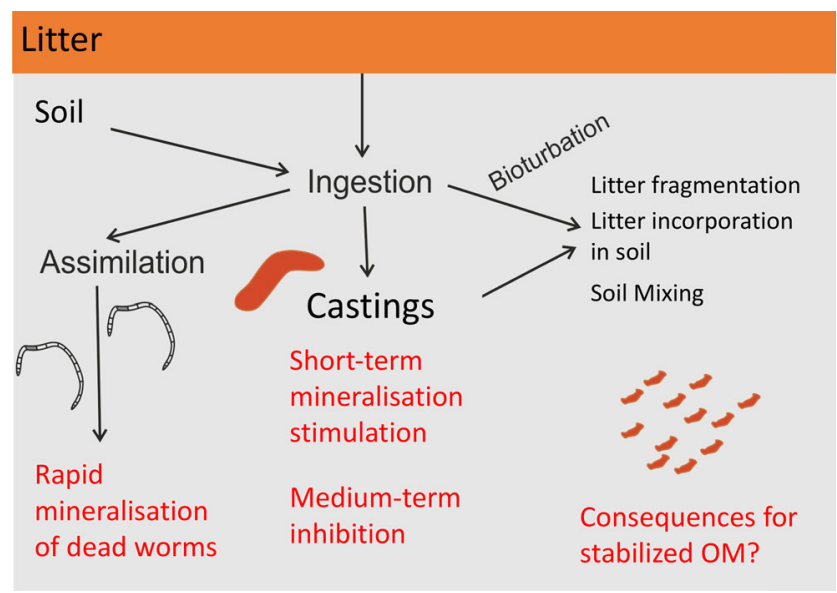

Fig. 3 Earthworm activity affects organic matter dynamics via litter consumption and soil particle ingestion

mixing soil by bioturbation in the profile and influencing dissolved OM transport (Bohlen et al. 2004).

Ecosystem engineers also promote $\mathrm{C}$ stabilisation by forming biogenic structures (biostructures such as castings, galleries, veneers, fungi wheels, termite or ant hills). The $\mathrm{C}$ in these structures can be stabilised through organomineral associations, depending on ingested OM composition (Vidal et al. 2016). The type, shape and characteristics of these biogenic structures vary depending on species, land-use patterns and seasons (Decaëns et al. 2001; Hedde et al. 2005; Mora et al. 2005). The $C$ distribution in these structures, e.g. concentration decreasing from the centre outwards, varies between species. For a given species, the $\mathrm{C}$ distribution in biogenic structures varies according to their habitats and depends on the soil depth (Don et al. 2008; Jiménez et al. 2008). The physical degradation rate of these structures influences $\mathrm{C}$ stabilisation time scale, as well as nutrient release and availability in soils (Le Bayon and Binet 2006; Mariani et al. 2007a; Mariani et al. 2007b; Jouquet et al. 2011). Furthermore, the type of OM (macro-debris, particulate matter or microbial metabolites) and its location (intra- or inter-aggregate), which differ between ecosystem engineers, are also drivers of $\mathrm{C}$ dynamics in these biogenic structures (Six et al. 2000; Bossuyt et al. 2004; Six et al. 2004; Bossuyt et al. 2005).

Processes promoting $\mathbf{C}$ mineralisation The transit of soil particles through the gut of macrofaunal organisms promotes contact between microbes and $\mathrm{OM}$, leading to alteration of the chemical structure of the OM. This alteration occurs (1) by selective digestion of peptide compounds which alters their stability (Shan et al. 2010), (2) through biochemical changes due to a succession of extreme $\mathrm{pH}$ or redox conditions (Brauman 2000) or (3) by physical remodelling of the particles (West et al. 1991). Many groups of soil fauna are known 
to stimulate microbial activity and OM mineralisation in the short term (Brown 1995; Winding et al. 1997).

Micro- and meso-fauna also contribute to the decomposition of litter and plant debris, in that their activity regulates the activity of the soil microbial communities. For example, the grazing of bacterial-feeding protozoa or nematodes tends to reduce the microbial density. However, it also stimulates the activity of the microbial communities, which tends to increase $\mathrm{OM}$ mineralisation rate. This is known as the microbial loop principle (Bonkowski 2004).

In conclusion, trophic activity and the production of biostructures by soil fauna, especially by the ecosystem engineers, impact soil $\mathrm{C}$ dynamics: OM mineralisation is often stimulated in the short term, but stabilised in the longer term. As a result, the quantitative effects are highly variable (Fig. 3). Further research is necessary to gain insight into and predict these effects, while taking the functional traits of the organisms and their environment into greater account. At larger spatiotemporal scales, the functional domain defined by the properties of biogenic structures (e.g. termitosphere, myrmecosphere or drilosphere) strongly influences $\mathrm{C}$ storage in the soil profile, which affects the overall ecosystem functioning.

There is also a lack of knowledge about (1) the impact of the biochemical quality of OM on its use by soil organisms since the OM they ingest is chosen not only according to its degradability but also to its stoichiometric composition, in relation to decomposer needs; and (2) the digestive system of organisms, its effect on microorganism selection and the effect of this selection on biogenic structures. Little is also known about the effect of changes in environmental conditions (water and nutrient availability) on biogenic structures. Research on the effects of cultivation practices (tillage, pesticide use, etc.) on the soil fauna density and on their trophic interactions that affect soil $\mathrm{C}$ stabilisation would also be necessary (see Section 3).

Finally, future research on $\mathrm{C}$ stabilisation mechanisms in soil hosting macrofauna should assess the balance between the beneficial effects of these organisms on $\mathrm{C}$ storage and their negative effects due to the GHG they emit $\left(\mathrm{CH}_{4}, \mathrm{~N}_{2} \mathrm{O}\right)$ (Lubbers et al. 2013; Chapuis-Lardy et al. 2010). In the long term, research projects should also consider the ability of soil fauna to generally positively influence plant biomass production (Scheu 2003), thus likely increasing soil OM inputs (see Section 2.1.1).

\subsubsection{Diversity and physiology of microorganisms - drivers of soil $C$ dynamics}

Within soil decomposers, microorganisms are the most taxonomically and functionally diversified component (Torsvik and Øvreås 2002; Curtis and Sloan 2005). It is estimated that $1 \mathrm{~g}$ of soil can host up to 1 billion bacteria, representing
1 million species (Gans et al. 2005), and up to 1 million fungi comprising up to 10,000 species (Hawksworth 1991; Bardgett 2005). However, the number of neighbouring microorganisms with which a single bacterium interacts, within a distance of about $20 \mu \mathrm{m}$, is relatively limited (120 cells on average) (Raynaud and Nunan 2014).

By their activity, microorganisms play a very important role in the ecosystem services provided by soils. At the ecosystem scale, soil microorganisms are vital with regard to (1) nutrient recycling $(\mathrm{N}$, phosphorus, sulphur, potassium, etc.), essential for plant growth and ecosystem dynamics; (2) soil OM storage, crucial for preserving the soil structure and fertility; and (3) soil OM degradation, which could dramatically change the global climate equilibrium (van der Heijden et al. 2008). Furthermore, microorganisms are the main source of organic compounds stabilised in the long term (compared to plants) (e.g. Simpson et al. 2007; Schimel and Schaeffer 2012), as indicated by studies using molecular biomarkers such as sugars and amino sugars, proteins and lipids (Derrien et al. 2006; Miltner et al. 2012).

The soil microbial compartment, despite its central role in soil OM transformation, is still often considered as a group of ubiquitous organisms with high functional redundancy (Nannipieri et al. 2003), on the basis of the postulate put forward by Beijerinck (1913) that 'everything is everywhere, but, the environment selects'. As such, microbial communities are still often included in compartment models of soil $\mathrm{C}$ dynamics as a functional black box generating fluxes whose intensity depends only on abiotic factors such as temperature, humidity, $\mathrm{pH}$, etc., thus excluding the hypothesis that the diversity and composition of microbial communities as well as trophic interactions (competition, commensalism, etc.) between populations can play a functional role (McGill 1996; Gignoux et al. 2001).

This vision could be partly explained by the technical limitations that have long hindered the characterisation of the vast diversity of microbial communities in soils, thus preventing (1) the identification of microbial populations involved in soil OM degradation and (2) the assessment of the role of microbial diversity in soil OM transformation. However, significant progress has been made (Fig. 4), especially since the beginning of the 'omics' era and the advent of molecular tools, which are currently able to characterise the taxonomic and functional diversity of communities in situ and without a priori (Maron et al. 2011; Nagy et al. 2016). Recent studies using these tools have suggested that microbial diversity is an important parameter that can modulate soil OM turnover, and thus the balance between soil $\mathrm{C}$ storage and atmospheric $\mathrm{CO}_{2}$ emissions (Tardy et al. 2015; Ho et al. 2014; Baumann et al. 2013; Bell et al. 2005). Future studies should improve the overall understanding of microbial mechanisms involved in this balance (complementary niches, facilitation, etc.). However, other studies have indicated that diversity does not have a role in the balance between $\mathrm{C}$ storage and $\mathrm{CO}_{2}$ 


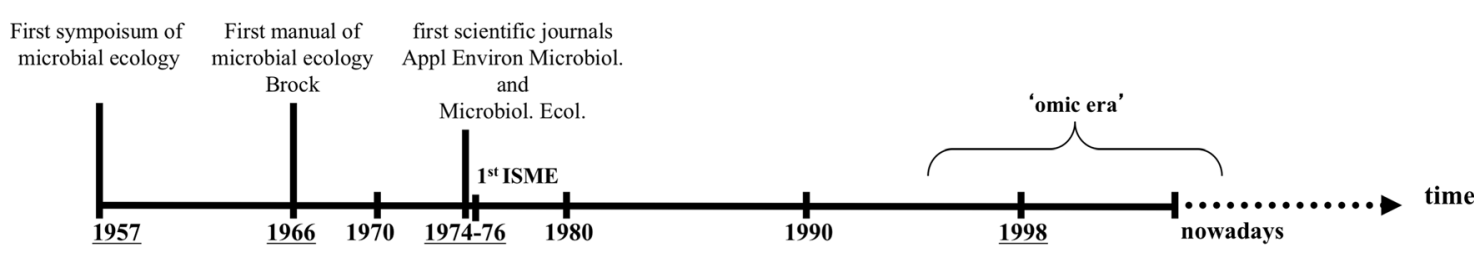

Integration level of studies in microbial ecology

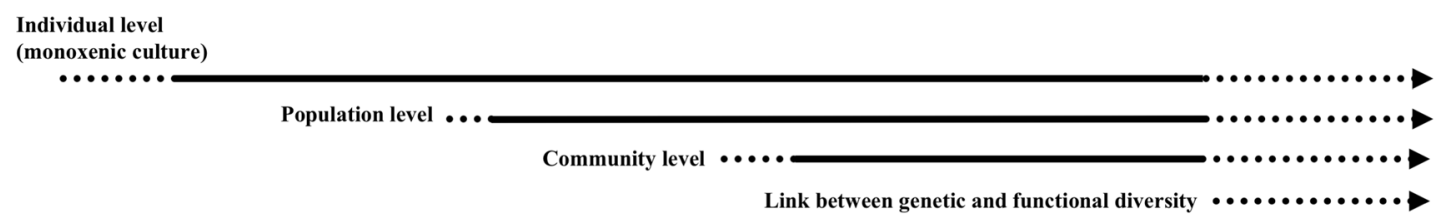

\section{Methodological developments}

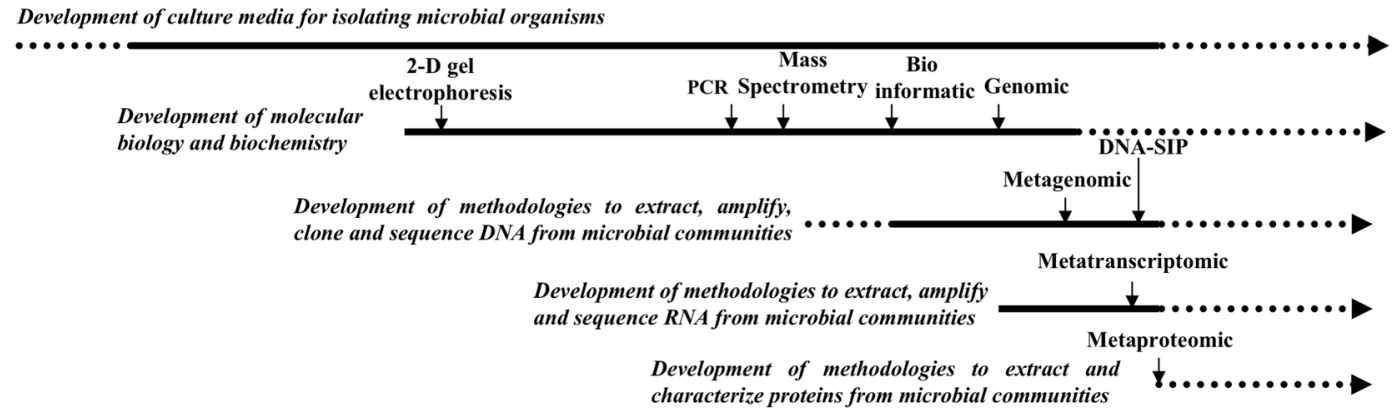

Fig. 4 History and methodological developments in microbial ecology. Excerpt from Maron et al. (2007), with permission of Springer

emissions (Wertz et al. 2006; Wertz et al. 2007; Griffiths et al. 2001 and Griffiths et al. 2008). Long-term studies at experimental sites but also in monitoring networks at national or international scales (Gardi et al. 2009) will help to gain insight into the spatiotemporal variability of processes related to microbial diversity and their impact on soil organic $\mathrm{C}$ storage.

Advances in microbial ecological knowledge are crucial for understanding how microorganisms use $\mathrm{C}$ and therefore impact its long-term fate in soil (Schimel and Schaeffer 2012). A substantial proportion of soil $\mathrm{C}$ originates from labile compounds metabolised by microorganisms and stabilised as microbial residues in organomineral complexes (Miltner et al. 2012; Clemmensen et al. 2013; Cotrufo et al. 2015; Haddix et al. 2016). The $\mathrm{C}$ use efficiency of microorganisms is used to estimate, for a given substrate, the ratio between mineralised $\mathrm{C}$ and $\mathrm{C}$ incorporated in soil OM. This $\mathrm{C}$ use efficiency varies depending on the microbial species and their physiology, nutrient availability (N, phosphorus, sulphur, etc.) necessary for microbial metabolism, interactions with the soil matrix and the environmental conditions (temperature, $\mathrm{pH}$, moisture, etc.) (Manzoni et al. 2012; Mooshammer et al. 2014; Geyer et al. 2016; Lashermes et al. 2016). Moreover, it is likely to change depending on the climatic and atmospheric conditions (Allison et al. 2010; Schimel 2013; Sistla et al. 2014).

Considering the major contribution of microbial communities in processes driving soil $\mathrm{C}$ dynamics, managing the microbial component could be a lever for optimising soil C storage (Jastrow et al. 2007). Future research should aim at classifying the impacts of climate parameters, land-use patterns and microbial diversity on $\mathrm{C}$ storage, while also focussing on improving the models by explicitly incorporating microbial diversity to improve the prediction of soil $\mathrm{C}$ dynamics.

\subsection{Abiotic soil organic C stabilisation mechanisms}

\subsubsection{Localisation in the physical structure of soil}

Soil is a heterogeneous environment, which has an impact on soil organic $\mathrm{C}$ dynamics. At the landscape scale, soil heterogeneity is driven by the soil texture and mineralogy, and by topology and management practices. At the plot scale, agricultural practices and plant species are the determinants of heterogeneity (Etema and Wardle 2002; Chevallier et al. 2000). At the fine process scale, the degree of heterogeneity depends on the soil physical structure, which corresponds to the spatial arrangement of solid particles (mineral particles, OM) and pores in which fluids, decomposers and soluble compounds circulate (Chenu and Stotzky 2002; Monard et al. 2012). Understanding how the soil physical structure affects OM dynamics is crucial with a view to preserving or even increasing organic $\mathrm{C}$ stocks in soils. On the one hand, climate change, and especially the water regime, affects the environmental 
conditions at the microbial habitat scale, while on the other, land use and agricultural practices markedly affect the soil structure.

As mentioned above, biotic processes can have a great effect on aggregation: plants with their roots, macrofauna when they digest organic and mineral soil components together, and microbes by acting on their close organomineral environment at the nanoscale. Abiotic $\mathrm{C}$ stabilisation mechanisms are thus highly linked to biotic mechanisms.

Soil organic $\mathrm{C}$ dynamics are slowed down by inclusion in aggregates From the mid-twentieth century, experimental studies have demonstrated that aggregation decreases the soil OM mineralisation rate (Rovira and Greacen 1957). Experiments were designed to measure $\mathrm{CO}_{2}$ production after grinding of soil aggregates and to compare it to the $\mathrm{CO}_{2}$ emitted by the same soil with preserved aggregates. The results showed that grinding increased soil organic $\mathrm{C}$ mineralisation, and that the rate increased with the fineness of the grinding. Since then, many studies based on physical fractionation methods have helped to isolate different types of soil aggregates and understand their roles in protecting OM. By analysing samples of soils that had undergone conversion from a $\mathrm{C}_{3}$ to a $\mathrm{C}_{4}$ photosynthesis type of vegetation (or the reverse), and using the difference in $\mathrm{C}$ isotopic composition between $\mathrm{OM}$ from $\mathrm{C}_{3}$ and $\mathrm{C}_{4}$ plant types, it was shown that (1) the $\mathrm{C}$ residence time was greater when plant debris was included in aggregates than when it was not associated with aggregates, and (2) the $\mathrm{C}$ residence time in micro-aggregates $(<50 \mu \mathrm{m})$ was longer than in macro-aggregates $(>50 \mu \mathrm{m})($ e.g. Golchin et al. 1994; Besnard et al. 1996; Six et al. 1998; Six and Jastrow 2002; Chevallier et al. 2004). However, the structural difference between micro- and macro-aggregates might not be the only factor that could explain these contrasted OM mineralisation rates because (1) the OM nature and quality may differ in micro- and macro-aggregates, (2) micro- and macro-aggregates might host different microbial communities (Hemkemeyer et al. 2015) and (3) the stability of macro- and micro-aggregates, which regulates the $\mathrm{OM}$ storage duration, is not the same (Plante and McGill 2002). However, aggregates, and especially micro-aggregates, are used as fractions to indicate the degree of physical protection of $\mathrm{C}$ as estimates of the pools involved in the compartment models on $\mathrm{C}$ dynamics at multi-annual time scales (e.g. Zimmermann et al. 2007, for RothC). Conceptual models describing $\mathrm{C}$ dynamics in different aggregates, considering aggregate formation-destruction cycles, have recently emerged, but their parameterisation is not yet possible since these models are too complex and not sufficiently constrained (Stamati et al. 2013).

Decomposers act on organic substrates in the soil pore network OM mineralisation requires contact between the substrates and decomposing microorganisms, or their enzymes, at the micrometre scale of the microbial habitat (Chenu and Stotzky 2002). Several recently developed techniques have helped gain insight into the mechanisms by which the physical structure of soil regulates OM mineralisation. Microtomography helps estimate the size and shape of the pores and their degree of connectivity. Nanoscale secondary ion mass spectrometry (nanoSIMS) and synchrotron radiation [scanning transmission x-ray microscope (STXM) and near edge $\mathrm{x}$-ray absorption fine structure (NEXAFS)] imaging can locate OM and microorganisms at the micrometre scale, while also providing chemical information complementary to that obtained through fluorescence microscopy studies of thin soil sections (Raynaud and Nunan 2014). It has been shown that OM-decomposer co-localisation accelerates biodegradation (Vieublé Gonod et al. 2003; Pinheiro et al. 2015; Don et al. 2013), while accessibility of OM to microbes might be a major driver of soil C dynamics (Dungait et al. 2012). This contact can occur by substrate and enzyme diffusion and advection, or via microorganism growth and mobility (Fig. 5). Furthermore, the local environmental conditions (oxygen, $\mathrm{pH}$, water content, etc.) at the micrometre scale have to be favourable for microorganism activity. The soil structure controls biodegradation at the micrometre scale (Juarez et al. 2013). The mineralisation rates of simple substrates thus depend on the size of the pores in which they are located (Killham et al. 1993; Ruamps et al. 2011) and could be related to the different microbial communities present in these habitats (Hemkemeyer et al. 2015; Hatton et al. 2015).

In conclusion, by combining experimental approaches involving microcosms, isotopic labelling, 3D imaging and modelling, significant progress should be achieved in the coming years in understanding how the soil structure controls OM dynamics and incorporating these controls into models. Studies at fine spatial scales will be particularly useful to link

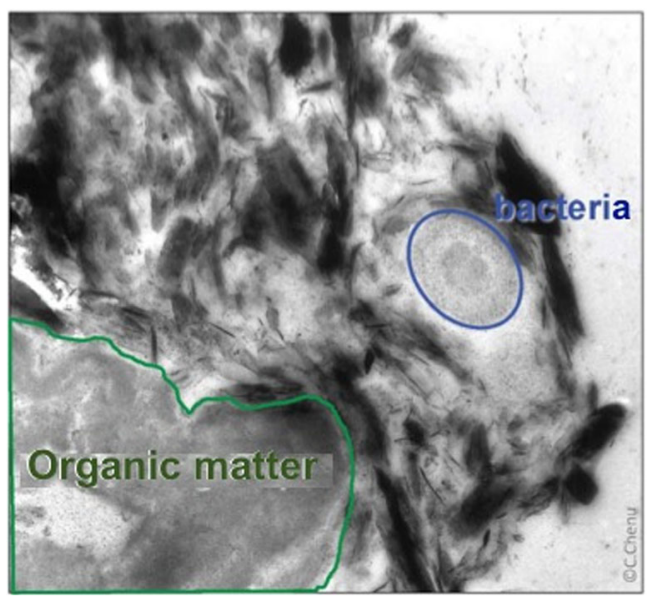

Fig. 5 Organic matter biodegradation requires direct contact between microorganisms or their extracellular enzymes and organic substrates, and local conditions favourable for microorganisms. This transmission electron microscopy image of a thin soil section shows that, even at the micrometric scale, microorganisms and organic materials can be physically separated (Chenu et al. 2014a) 
C storage mechanisms to the soil $\mathrm{C}$ saturation concept, as discussed in the third part of this review (Section 4).

\subsubsection{C stabilisation mechanisms involving organomineral interactions}

Mineral protection of soil $\mathrm{OM}-$ an old story The idea that soil OM can be protected from the mineralising activity of microorganisms by soil minerals emerged more than 200 years ago (Thaer 1811 in Feller and Chenu 2012). This protection has been included in soil C dynamics models for over 70 years (Henin and Dupuis 1945). Smaller minerals, mainly contained in the clay particle-size fraction (less than $2 \mu \mathrm{m}$ ), most efficiently protect $\mathrm{OM}$. This particle-size class consists of a variety of minerals: clay minerals (phyllosilicates), as well as different forms of metallic oxyhydroxides and poorly crystallised aluminosilicates (allophane or imogolite types). These finely divided minerals protect OM by adsorption (e.g. Jones and Edwards 1998) or by trapping OM within sub-micron aggregates, thus physically protecting it from the degrading action of soil microorganisms (Chenu and Plante 2006). The OM degradation rate is also decreased, and stabilisation increased, when organic molecules are located in parts of the pore network (neck diameter between 10 and $1000 \mathrm{~nm}$ ) that are saturated with water, thus limiting oxygen and enzyme diffusion (Zimmerman et al. 2004; Chevallier et al. 2010).

\section{Chemical interactions and heterogeneous soil OM distri-} bution OM adsorption by soil minerals may derive from different types of interaction: anionic ligand exchange, cationic ligand exchange, cationic bridges or so-called weak interactions (including van der Waals forces, hydrogen bonding, hydrophobic interactions). The type of interactions involved depends on the mineral phases and OM chemical functions (von Lützow et al. 2006). Although theoretically these different types of interactions are expected, it is however very difficult to directly observe them in soil samples and to highlight any chemical specificity of organomineral interactions using current state-of-the-art techniques (Lutfalla 2015).

Moreover, direct observations on natural samples using microscopic techniques combined with increasingly powerful characterisation tools (atomic force microscopy, nanoSIMS, STXM-NEXAFS, etc.) showed that OM is adsorbed on mineral surfaces in the form of patches and does not cover the entire particle surface (e.g. Ransom et al. 1998; Chenu and Plante 2006; Remusat et al. 2012; Theng 2012; Rumpel et al. 2015). An isotopic labelling study further revealed that newly adsorbed OM preferentially binds to existing patches and not to free mineral surfaces (Vogel et al. 2014). These results suggest that the capacity of different minerals to protect OM would depend on their ability to adsorb a large number of patches. This could explain why the correlation between specific mineral surfaces and their ability to protect $\mathrm{OM}$ is poor or nonexistent (Kögel-Knabner et al. 2008).

High importance of low-crystallised mineral forms and mineral weathering Andosol observations, chemical extraction results and fine-scale observations suggest that poorly crystallised mineral forms (pedogenic oxides and amorphous or slightly crystallised aluminosilicates) are particularly efficient in stabilising soil OM (Torn et al. 1997; Kleber et al. 2015). They complex soil organic compounds to form organomineral nano-complexes (noted here nanoCOMx), a few nanometres to a few hundreds of nanometres in size, which contain high $\mathrm{C}$ concentrations. They can be observed by direct transmission electron microscopy analysis (Wen et al. 2014). Close correlations between the metallic oxyhydroxide and $\mathrm{C}$ contents have been highlighted using indirect chemical extraction methods (Bruun et al. 2010; Mikutta et al. 2006), thus demonstrating the importance of nanoCOMx for soil OM stabilisation. NanoCOMx have mainly been studied in controlled conditions whereby they are synthesised by adsorption and co-precipitation (especially for $\mathrm{Fe}$ and $\mathrm{Al}$ ) in batch experiments, but further research is needed on the identification and quantification of these mechanisms in soils (Kleber et al. 2015).

Andosols, which have a particularly high OM content, are the systems of choice for studying nanoCOMx formation in soils (Torn et al. 1997). The weathering of primary mineral phases produces partially crystallised phases (protoimogolites), which complex the OM before reaching their final crystalline growth stages (imogolite and/or allophane). These proto-imogolite/OM interactions thus have a dual feedback effect: (1) they stabilise organic compounds over periods of up to several thousands of years (Basile-Doelsch et al. 2005), and (2) they stop crystal growth of the secondary mineral phases (Levard et al. 2012). Based on these mechanisms, a new conceptual model of soil OM stabilisation was proposed to highlight the synergy between the continuous alteration of minerals and nanoCOMx formation dynamics (Basile-Doelsch et al. 2015) (Fig. 6). The findings of some studies carried out on mineral surfaces tend to confirm this model (Bonneville et al. 2011; Kawano and Tomita 2001). Future research is needed to validate this model on various mineralogical phases in different soil types.

Finally, unlike crystallised minerals, the kinetics of alteration of poorly crystallised minerals in soils may span just a few years to decades, which is of the same order of magnitude as the time scales at which $\mathrm{C}$ dynamics are considered in the climate change context. Contrary to general opinion, OM mineralisation in organomineral complexes could well be due to destabilisation of mineral phases, which are no longer regarded as immutable at yearly to decadal timescales. Keiluweit et al. (2015b) showed, for example, that some oxalate type constituents of root exudates destabilised 


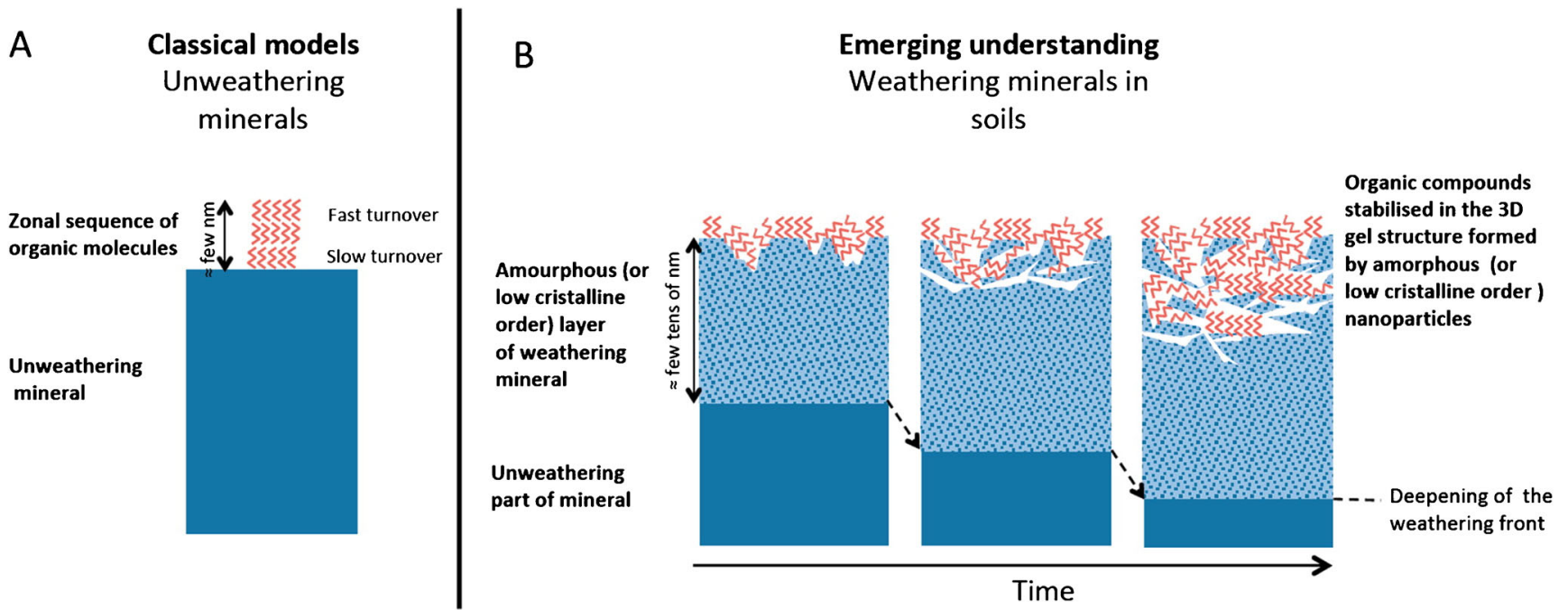

Fig. 6 Conceptual models of organomineral interactions differing with regard to the mineral surface properties. a In conventional models, organic compounds form a series of layers, and the turnover rate decreases when the molecule gets closer to the mineral surface. $\mathbf{b}$ The model proposed by Basile-Doelsch et al. (2015) considers that the

oxyhydroxide minerals and released initially complexed native OM. These compounds, which become accessible to microorganisms, may be mineralised. The destabilisation of nanoCOMx mineral components has also been shown in agricultural systems (Wen et al. 2014), and in some cases associated with substantial OM loss.

Until recently, analytical methods have not been effective to achieve sufficiently detailed characterisation of the organic component of organomineral complexes to highlight differences depending on the mineral phases to which they are associated. Future research on organomineral complexes will benefit from recent progress in analytical methods. To enhance integration of theoretical knowledge of these complexes, future studies on their formation and dynamics will have to move from the laboratory to the field in order to understand how these mechanisms are affected by agricultural practices.

\section{Mechanisms of OM dynamics affected by agricultural practices}

The soil C stock depends primarily on land-use patterns. For French soils, Martin et al. (2011) showed that the 0 to $30 \mathrm{~cm}$ mineral horizons contained on average $80 \mathrm{tC} \mathrm{ha}^{-1}$ under forest and grassland, $50 \mathrm{tC} \mathrm{ha}{ }^{-1}$ under crops and $35 \mathrm{tC} \mathrm{ha}^{-1}$ in vineyard soils (Table 1). Any land-use change therefore has a marked effect on the $\mathrm{C}$ stock. Meta-analyses on this subject have shown massive $\mathrm{C}$ loss following the cultivation of forests and grasslands. The meta-analysis of Guo and Gifford (2002), based on 74 publications, showed that soil $\mathrm{C}$ decreases when cropland replaces native forest $(-42 \%)$ and pasture $(-59 \%)$. It alteration of minerals generates nanometre amorphous minerals. Their high reactivity and specific surface area promote their interactions with organic compounds (excerpt from Basile-Doelsch et al. 2015, with permission of ACS Publications)

also revealed a drop in C stocks from plantations to grassland $(-10 \%)$ and from native forest to plantations $(-13 \%)$. The rapid decrease in $\mathrm{C}$ stocks in cultivated soils can be explained by the generally lower C inputs (Lal et al. 2004) and faster OM mineralisation rates due to more intense tillage, which mixes deeper soil horizons and partly destroys the aggregation (Wei et al. 2014). However, soil C stocks increase after conversion from native forest to pasture $(+8 \%)$, crop to pasture (19\%), crop to plantation $(+18 \%)$ or crop to secondary forest $(+53 \%)$ (Guo and Gifford 2002). Observations by Attard et al. (2016) showed the asymmetry of the mechanisms: the loss of organic C stocks after cultivation of grassland soil was fast while the replenishment of these stocks was slow because it depends on the slow installation and growth of plant roots in the previously cultivated soil. Furthermore, recent observations showed that $\mathrm{C}$ stock evolution related to land-use changes are mediated by soil parent material (Barré et al. 2017): the differences in soil C stocks between old forests and croplands were higher on calcareous bedrocks than on loess deposits.

Operationally, these results concerning the impacts of landuse changes on soil $\mathrm{C}$ stocks underline the fact that the spatial patterns of land-use or rotations must be considered with caution. However, soil C stocks also depend on the agricultural practices implemented, which determine the input and output $\mathrm{C}$ fluxes in soils, depending on soil and climatic conditions. The following section identifies the main agricultural practices and examines their impact on the soil C stock.

\subsection{Review of the main agricultural practices}

Various management operations (Table 1) can be implemented depending on the land use. The following categories can be 


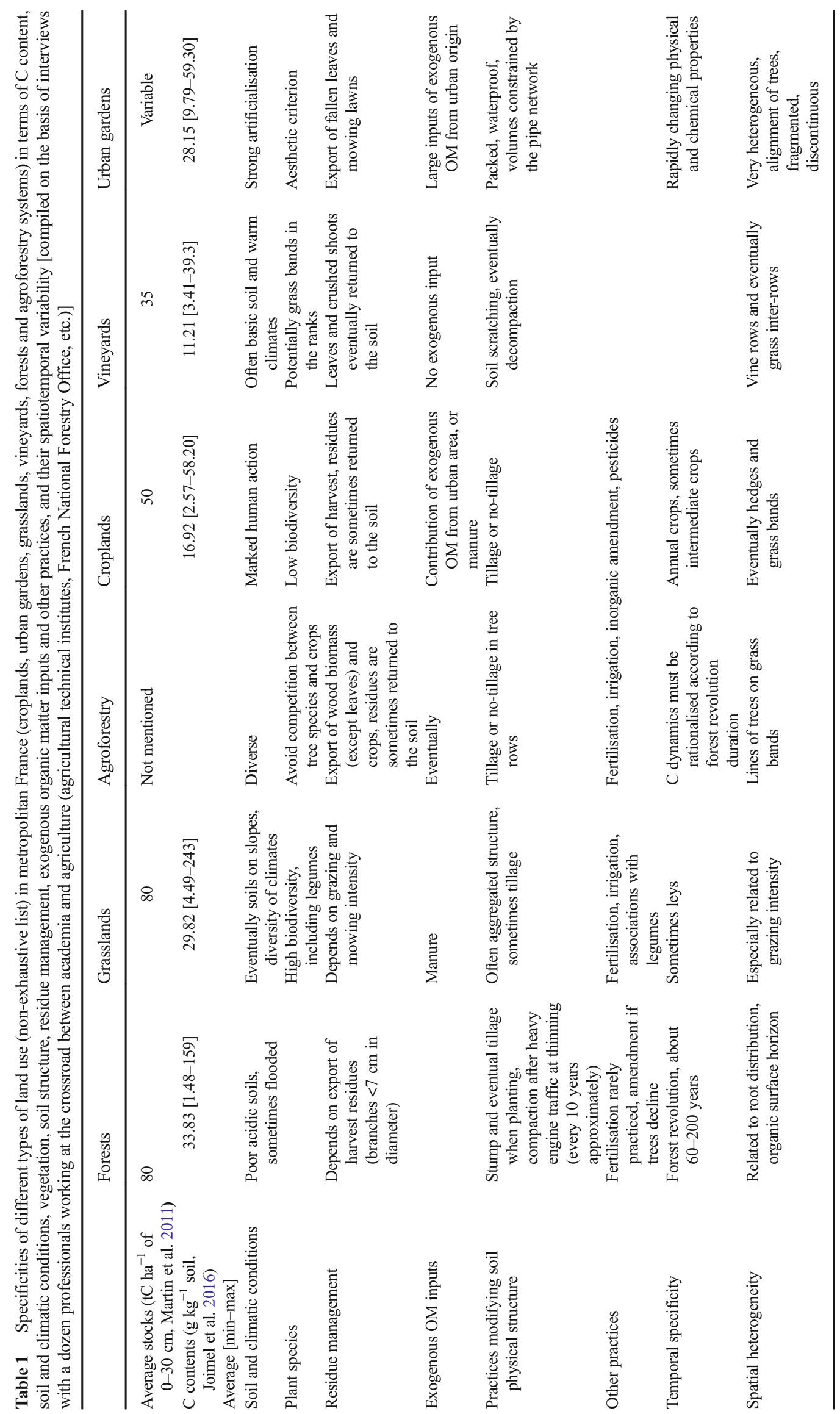


distinguished: choice of plant species, vegetation density, plant export intensity (crop residues returned to the soil or exported, grazing/mowing of grasslands, export of harvest residues in forest ecosystems, etc.), addition of exogenous $\mathrm{OM}$, irrigation, fertilisation, tillage, etc. These practices mainly control the spatiotemporal distribution of OM inputs to soil, along with the sensitivity of $\mathrm{OM}$ to mineralisation, both of which affect soil OM stocks (Jastrow et al. 2007).

Choice of plant species The choice of plant species has an effect on the chemical quality of soil OM (Rumpel et al. 2009; Armas-Herrera et al. 2016) and modifies the processes governing the dynamics of soil organic C. In forests, for example, although aboveground litter production is similar for softwood and hardwood trees, the litter degradation mechanisms differ (Berg and Ekbohm 1991; Osono and Takeda 2006). In deciduous forest, litter generally decomposes faster and the residues are more deeply incorporated in the soil profile because of the biochemical properties of their tissues and their impact on the soil chemistry, thus impacting, for example, the presence and activity of earthworms (Augusto et al. 2015). As noted above (Section 2.1.2), these organisms have a strong influence on soil OM dynamics. In grasslands, legume-grass associations promote soil $\mathrm{C}$ storage ( $\mathrm{Li}$ et al. 2016). In agricultural systems, varieties allocating more resources to the harvested part (grain) are often selected to increase yields. This selection decreases the biomass allocated to vegetative parts, including roots which contribute more than other plant organs to the intermediate OM pool (Section 2.1.1)

Soil OM inputs The intensity of plant harvesting for plantation management directly impacts plant-derived soil OM inputs (leaf litter, crop residues, roots, etc.). In grasslands, these inputs depend on the number of grazing animals and the mowing frequency (Conant et al. 2001); in agricultural systems, on crop residue export (Saffih-Hdadi and Mary 2008); in forests, on the thinning regime and the exportation of branches of less than $7 \mathrm{~cm}$ diameter (called harvest residues) (Jandl et al. 2006); inputs in urban soils depend on the mowing frequency in parks and on the removal of fallen leaves (Qian and Follett
2002; Lal and Augustin 2011). Exogenous OM is sometimes added to reduce chemical input and to recycle waste. Exogenous OM may be animal manure (Chotte et al. 2013), compost or sewage sludge (Hargreaves et al. 2008; Lashermes et al. 2009), or pyrogenic residues (biochar) (Steiner et al. 2007; Andrew et al. 2013).

The frequency and spatial distribution/localisation of soil OM inputs differ amongst land uses. It is assumed that vegetation cover present throughout the year increases soil OM inputs, as it is the case for permanent grassland, under grass bands or when intermediate crops are cultivated during the winter season. $\mathrm{C}$ dynamics in soils under ley grasslands show a legacy grassland effect during cropping years, leading to longer residence times of $\mathrm{C}$ in their fine fractions compared to continuously cropped soils (Panettieri et al. 2017). Soil OM inputs in forests are also a function of the age of trees at cutting (input of younger trees being lower than input of older ones). Spatially, the distribution of plant inputs may be modulated (Fig. 7) by seeding (or planting) density, by the localised addition of composts, by planting of grass bands in vineyards, by growing hedges in croplands or rows of trees in agroforestry systems or by aesthetic management of parks and gardens in urban areas (Freschet et al. 2008; Strohbach et al. 2012; Kulak et al. 2013; Cardinael et al. 2015).

These practices can increase the quantities of $\mathrm{C}$ added to the soil, but the extent to which they also affect $\mathrm{C}$ stabilisation mechanisms is unclear. Additional soil OM mineralisation can, for example, be observed following a fresh OM input (see the priming effect paragraph, Section 2.1.1).

Practices that stimulate both primary production and decomposer activity Tillage, soil decompaction after heavy machinery passages or removal of stumps after clear-cutting a forest stand are also practices that impact not only primary production and soil OM inputs but also OM mineralisation and therefore soil to atmosphere $\mathrm{C}$ fluxes. These operations affect soil properties, likely including its structure, decomposer activity (Lienhard et al. 2013) and consequently soil organic C stocks (see Section 2). Primary production and decomposer activity are also impacted by facilities for soil and water conservation in dry areas, by the use of inorganic amendments or
Fig. 7 The spatial distribution of organic matter can be modulated by localised compost inputs (a Madagascar) or by setting up rows of trees in the plots (b Agroforestry, Melle, France). Source: $\mathrm{T}$ Chevallier and $\mathrm{R}$ Cardinael

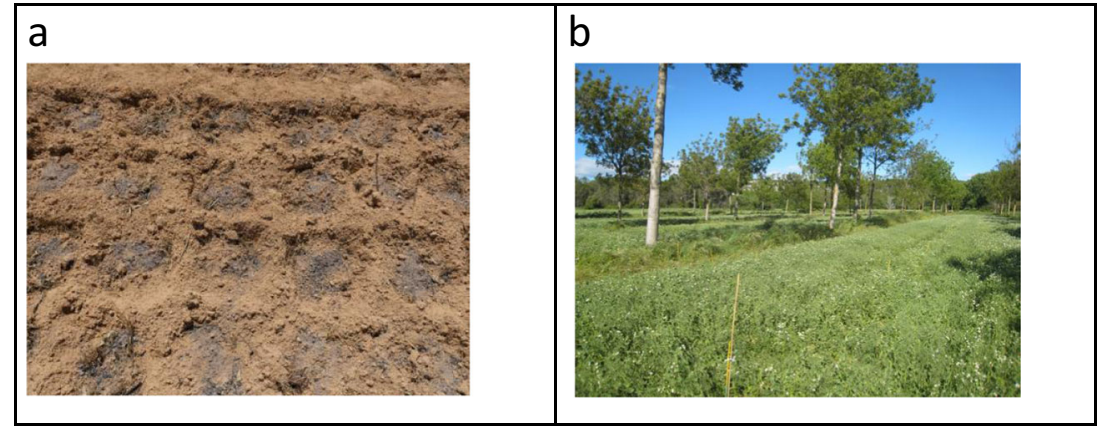


by systematic fertilisation in some cropping regions or in urban gardens (Miller et al. 2005; Edmondson et al. 2012). However, for economic reasons, fertilisation practices are very limited in forests or in poor agricultural areas.

\subsection{Impact of agricultural practices on soil organic C storage}

French experimental field studies on long-term variations in soil C stocks Numerous studies have already been conducted on the effects of agricultural practices on soil $\mathrm{C}$ storage. We present the results of three recently published experiments located in France spanning decadal to multi-decadal periods. One study concerns forests under conventional management, while two were focused on large-scale cropping systems with exogenous OM amendments or reduced tillage.

Changes in $\mathrm{C}$ stocks in forest soils were monitored in the French Permanent Plot Network for the Monitoring of Forest Ecosystems (RENECOFOR) by repeated measurements in 102 plots managed by the French National Forestry Office at 15-year intervals (Jonard et al. 2017). The observations revealed an average annual increase in $\mathrm{C}$ stock of $0.34 \mathrm{t} \mathrm{ha}^{-1}$ year $^{-1}$. This precisely corresponds to a $4 \%$ annual increase (average stocks in litter and in the top $40 \mathrm{~cm}$ soil horizon were $\left.81.6 \mathrm{tC} \mathrm{ha}^{-1}=0.34 / 81.6=0.004\right)$. The stock increase was larger in coniferous than in deciduous forests (Jonard et al. 2017) and was not linked to increased aboveground inputs. Weak links were noted with the litter quality $(\mathrm{C} / \mathrm{N})$, the history and management of the stand (regular vs. irregular forests).

The effects of the addition of exogenous OM were studied in the Qualiagro long-term field experiment, located at Feucherolles, near Paris (France). Various composts and manures were applied at a rate of $4 \mathrm{tha}^{-1}$ every other year. The soil $\mathrm{C}$ contents, measured every other year for 15 years, showed significant $\mathrm{C}$ accumulation, i.e. $0.20-0.50 \mathrm{tC} \mathrm{ha}^{-1}$ year $^{-1}$ for soil amended with manure and urban compost (Peltre et al. 2012). These organic amendments thus had a positive effect on C storage, in addition to economic and agronomic benefits (improvement of soil fertility and physical structure). However, negative effects were observed, particularly related to fluxes of elements other than C. Organic amendments often contain large quantities of $\mathrm{N}$ and $\mathrm{P}$, thus inducing a risk of over-fertilisation, $\mathrm{N}_{2} \mathrm{O}$ emission and $\mathrm{NH}_{3}$ volatilisation. Organic amendments also present a risk associated with the organic contaminants, metal contaminants or pathogens that they may contain (Smith 2009). It is necessary to better characterise the OM input, the reversibility of its accumulation and effects on the dynamics of other elements (N, $\mathrm{P}$, etc.) in order to better understand and predict the positive and negative effects of waste-derived organic amendments (Noirot-Cosson et al. 2016).

The long-term effects of tillage were studied for 41 years in a large-scale cropping area in the Paris Basin (Boigneville) (Dimassi et al. 2014). In this field experiment, no significant effects of tillage or crop management were observed on $\mathrm{C}$ stocks over 41 years. Reducing tillage, however, resulted in rapid soil $\mathrm{C}$ accumulation in the first 4 years, and then the $\mathrm{C}$ stocks only slightly changed over the next 24 years $\left(+2.17 \mathrm{tC} \mathrm{ha}^{-1}\right.$ with reduced tillage, $+1.31 \mathrm{tC} \mathrm{ha}^{-1}$ with no tillage), but additional stored $\mathrm{C}$ was later lost (Dimassi et al. 2014). The lack of ploughing caused soil OM stratification and changes in soil functioning, nutrient availability, soil water holding capacity, microbial diversity, the amount of fresh C incorporated in the soil and, accordingly, the priming effect. The water regime could be the determining factor of $\mathrm{C}$ storage/destocking in these situations. OM mineralisation was favoured during wet years or when the soils were irrigated, particularly at the surface where the majority of $\mathrm{C}$ accumulated when ploughing was stopped. Conversely, $\mathrm{C}$ accumulated during dry years. As already suggested by Balesdent et al. (2000), this study highlighted the importance of identifying, quantifying and classifying the different mechanisms according to the soil and climatic conditions in order to be able to model and predict soil organic $\mathrm{C}$ stocks under different agricultural and forestry practices.

Meta-analyses Meta-analyses are useful for comparing results obtained in various long-term studies in similar experimental fields to determine whether the processes triggered by a specific agricultural practice are widespread. Hereafter, we present some examples of recently published metaanalyses on the impacts of irrigation (Zhou et al. 2016), tillage (Virto et al. 2012), liming (Paradelo et al. 2015) and fertilisation (Han et al. 2016; Yue et al. 2016) on soil C stocks.

The findings of a meta-analysis by Zhou et al. (2016) suggested that the water availability changed the plant $\mathrm{C}$ allocation and the soil OM turnover. Drought led to an increase in the root/shoot ratio and a decrease in heterotrophic soil respiration, while irrigation led to an increase in soil respiration but also to higher biomass inputs.

Regarding soil tillage, the meta-analysis of Virto et al. (2012) shows the same trends as the long-term observation by Dimassi et al. (2014). No-tillage had little effect on the soil organic C stocks (see also Luo et al. 2010). However, secondary practices of no-till cropping systems (implemented to offset the lack of tillage, as the choice of cropped species and the number of rotations) showed positive effects on $\mathrm{C}$ storage (Virto et al. 2012).

Paradelo et al. (2015) reviewed the results of 29 studies considering the effects of liming on soil $\mathrm{C}$ stocks. Their meta-analysis did not reveal an unambiguous effect of liming on $\mathrm{C}$ storage. The compiled studies had been carried out under a wide range of experimental conditions. Moreover, they did not allow quantification of the three key processes driving the dynamics of organic $\mathrm{C}$ in soils affected by liming: crop 
production, decomposer activity and soil structure (see Section 2).

Yue et al. (2016) compared 60 studies on the impact of $\mathrm{N}$ inputs on $\mathrm{C}$ stocks. Their meta-analysis highlighted an increase in soil $\mathrm{C}$ inputs and no change in output fluxes related to increased $\mathrm{N}$ inputs. Regarding organic $\mathrm{C}$ stocks, the results showed an increase in $\mathrm{C}$ in the organic horizons and the soil solution, but no change in the $\mathrm{C}$ stock in the mineral soil horizons, contrary to the findings of the meta-analysis on forest soils conducted by Janssens et al. (2010). However, metaanalyses average the results obtained in different contexts and with different timescales, which may overlook effects that could be observed at a given site. The meta-analysis of Han et al. (2016) confirmed the results of Yue et al. (2016). If fertilisation is complemented by organic amendments, then the increase in $\mathrm{C}$ stocks would be even higher since organic amendments directly contribute to soil OM stocks.

In conclusion, due to the lack of knowledge on the mechanisms impacted by agricultural practices, it is hard to predict their effects on soil C stocks. Agricultural practices, which increase soil OM inputs, are often considered to have a positive impact on C storage (Pellerin et al. 2013; Chenu et al. 2014b; Paustian et al. 2016). However, their impact on mechanisms that contribute to the storage/destocking of soil C (see Section 2) are not yet clearly understood. Meta-analyses and long-term field studies showed that the relative intensity of mechanisms contributing to storage and those contributing to destocking may change over time. These studies also showed that it is essential to understand how the soil and climatic conditions modulate soil organic $\mathrm{C}$ stabilisation mechanisms.

In addition, while considering practices in terms of the $\mathrm{C}$ cycle and increased soil $\mathrm{C}$ stocks, the importance of interactions with cycles of other nutrients present in $\mathrm{OM}(\mathrm{N}, \mathrm{P}, \mathrm{S}$, etc.) should not be overlooked. Finally, regardless of the land use, it should be kept in mind that the main challenge for all agricultural stakeholders is to ensure a production level that will provide enough food in the context of world population growth and sufficient income for farmers, while maintaining employment. Preserving or increasing OM stocks are also levers with regard to these issues (Manlay et al. 2016).

\section{How could a better accounting of OM stabilisation mechanisms improve the prediction of soil organic $\mathrm{C}$ stock evolution?}

Working at the scale of mechanisms often implies working at fine spatial scales $(\mathrm{mm}-\mu \mathrm{m})$, only assessing the potential role of specific mechanisms and studying them in specific conditions (laboratory experiments or experiments in specific soil and climatic conditions). Predicting changes in the soil organic $\mathrm{C}$ stock through the understanding of mechanisms raises at least two crucial related issues that will be discussed in this section: (1) upscaling (from $\mu \mathrm{m}^{3}$ to $\mathrm{dm}^{3}$ and then to the plot, landscape and global scale) and (2) validation (from the potential action of a mechanism to its quantitative expression in different soil and climatic contexts). Regarding the upscaling issue, there are at least three possibilities: (1) finding an indicator that describes one or more mechanisms, (2) introducing more mechanisms in soil organic $\mathrm{C}$ dynamics models (RothC or Century types) or (3) identifying variables measured at the microscopic scale that allow, through appropriate modelling, prediction of macroscopic trends. Each of these approaches must then be validated on suitable datasets (Fig. 8).

\subsection{Finding indicators to improve prediction of changes in soil organic $\mathrm{C}$ stocks}

Several indicators have or could be developed to improve the prediction of soil organic $\mathrm{C}$ stocks, particularly in a context of land use and practice changes (see IPCC 2006, detailing the method currently used to estimate changes in soil C stocks).

The most currently discussed indicator is probably the $\mathrm{C}$ saturation deficit. Hassink (1997) proposed that the proportion of the fine fraction $(<20 \mu \mathrm{m})$ of a soil implies an upper limit to its capacity to store stable $\mathrm{C}$. This theoretical limit can be calculated $\left(C_{\mathrm{sat}}\right)$ by particle-size measurements $\left(C_{\mathrm{sat}}=4.09+0.37 \times(\right.$ clay + fine silt $\left.)\right)($ Hassink 1997). Sequestration by the fine fraction is due to the physical and physicochemical protection provided by finely divided minerals (see Section 2.2.2). The $\mathrm{C}$ saturation deficit is obtained by subtracting this theoretical $C_{\text {sat }}$ value from the actual OM concentration in the fine fraction of the soil. This indicator has recently been used to draw the first map of the potential of organic $\mathrm{C}$ storage in the fine fraction in the $0-30 \mathrm{~cm}$ horizon of French soils (Angers et al. 2011). However, this indicator of the potential gain of soil organic $\mathrm{C}$ has so far never been validated and its relevance for predicting $\mathrm{C}$ stock patterns consecutive to a change in land use or farming practices remains to be evaluated (O'Rourke et al. 2015).

Another approach, somewhat similar to that of Hassink (1997), was proposed to assess French soil C storage capacity. Rémy and Marin-Laflèche (1974) defined some benchmark OM levels according to clay and carbonate soil contents. Roussel et al. (2001) used this chart to estimate the OM deficit compared to the benchmark OM contents for French soils. The authors thus subtracted OM contents referenced in the French Soil Analysis Database (BDAT) from the benchmark OM contents listed on the chart proposed by Rémy and Marin-Laflèche (1974). However, the link between the potential of OM gain and the OM deficit calculated using the Rémy and MarinLaflèche (1974) chart remains to be validated and the area of validity of this chart is still an open issue (Roussel et al. 2001).

Conversely, indicators of the risk of soil organic $\mathrm{C}$ loss could be developed. For example, $\mathrm{C}$ in a soil with a high 


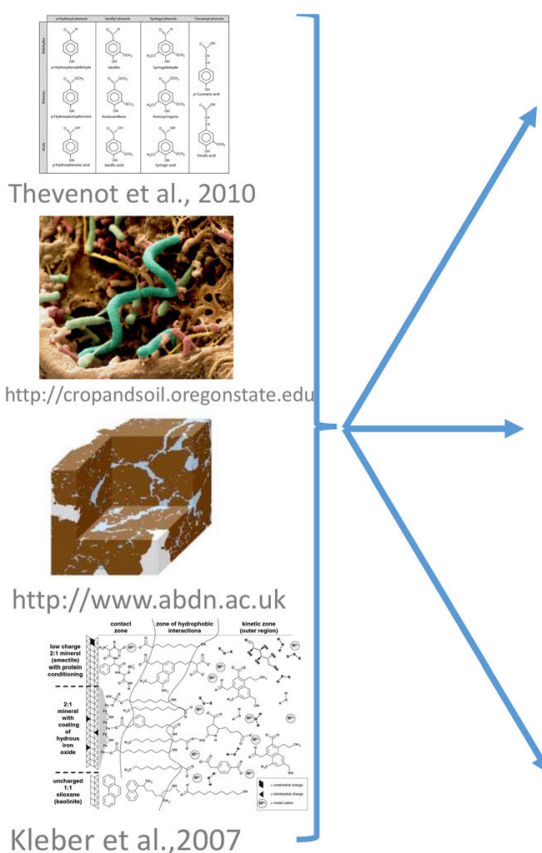

Mechanisms
Mechanisms are implicitely taken into account into indicators (e.g. C saturation deficit)

Mechanisms are implicitely taken into account in ecosystem models (e.g. lignin/N ratio, $\mathrm{C}$ decay rates modified by clay content...)

Mechanisms are explicitely taken into account in models with a $\mu \mathrm{m}$ scale resolution

How mechanisms are taken into account

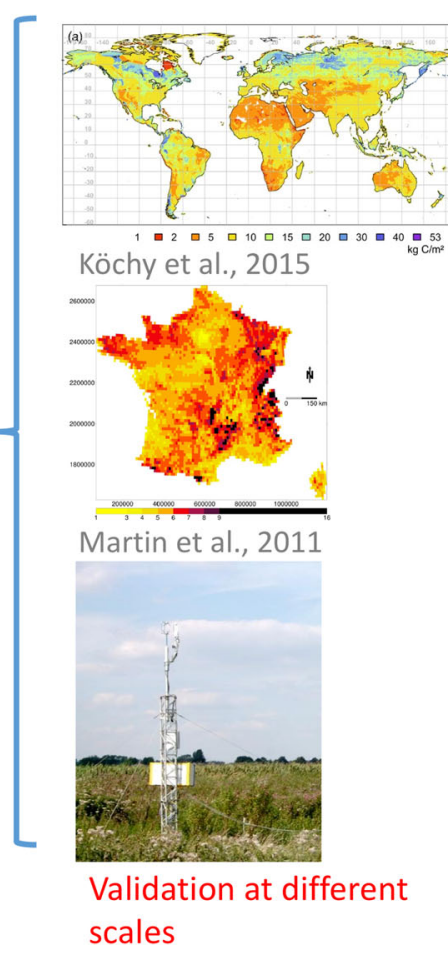

Fig. 8 From the identification of stabilisation mechanisms to their effective consideration to improve the prediction of soil organic $\mathrm{C}$ stock evolution

particulate OM content may be more rapidly lost compared to $\mathrm{C}$ in a soil that has a greater portion of $\mathrm{C}$ associated with the mineral matrix (Arrouays 1994; Jolivet et al. 2003). Particulate OM contents, which are easily measured by standardised methods, could thus be an indicator of the potential for soil $\mathrm{C}$ loss. Other studies suggest that the biogeochemical stability of $\mathrm{C}$ might be connected to its thermal stability (Plante et al. 2011; Saenger et al. 2013, 2015; Barré et al. 2016). In this case, thermal measurements could serve as a proxy for assessing the amount of organic $\mathrm{C}$ that may be lost following a land use or cropping practice change. Using thermal measurements to assess the $\mathrm{C}$ sequestration potential could also be considered.

Other indicators based on biotic mechanisms of soil organic $\mathrm{C}$ sequestration (see Section 2.1) could probably be used, such as the bacteria/fungi ratio or indicators based on soil fauna, vegetation or litter layer. Soil type and mineralogy are also potential relevant indicators (Mathieu et al. 2015; Khomo et al. 2016). It should be kept in mind that the measurement of these indicators should be rapid and inexpensive to enable them to be tested in a large variety of soil and climatic contexts. Finally, the indicator necessarily represents the sequestration mechanisms in partial and degraded form, but its predictive value will only be satisfactory if it has a sound scientific basis and has been subject to a specific validation process. These conditions have currently not been met for any indicator, thus broadening the prospects for research, validation and implementation of such indicators of soil $\mathrm{C}$ stock changes. In addition, selecting relevant indicators for $\mathrm{C}$ storage initiatives is still a complicated task. Indeed, indicators could trace the $\mathrm{C}$ storage potential of soils (like those described above) or other variables such as the storage rate, input fluxes, average mineralisation rate, mean residence time in soil, etc.

\subsection{Better integration of OM stabilisation mechanisms in large-scale $\mathbf{C}$ dynamics models}

The prediction of the evolution of $\mathrm{C}$ stocks by Earth-system models is very uncertain (e.g. Friedlingstein et al. 2006). A comparison of Earth-system models showed, for a given anthropogenic GHG emission change scenario, that these models can predict a soil organic $\mathrm{C}$ stock evolutionary pattern for the twenty-first century ranging from -50 to $+300 \mathrm{GtC}$ (Eglin et al. 2010). The difference between the extremes of the predicted values corresponds to about $40 \%$ of the current atmospheric $\mathrm{C}$ stock. A better prediction of the evolution of the atmospheric $\mathrm{CO}_{2}$ concentration is crucial to reduce uncertainties about soil $\mathrm{C}$ stock changes. Soil $\mathrm{C}$ stabilisation mechanisms are not yet taken into sufficient consideration in largescale models (Luo et al. 2016). In particular, biological regulation (macrofauna, microorganisms) and soil structure (Wieder et al. 2015) are barely taken into account in these models despite the fact that they are major drivers of soil $\mathrm{C}$ dynamics, as noted above (see Section 2).

Furthermore, most of these models fail to reproduce the interactions between primary production and organic $\mathrm{C}$ 
residence time in soils. These two variables control the amount of $\mathrm{C}$ stored in soils, but independently (Todd-Brown et al. 2013). However, explicitly integrating stabilisation mechanisms into these models is a difficult task. We must first find a suitable mathematical formalism to describe the mechanism to be added, incorporate it into the model and test whether the model performance has actually been improved.

By this approach, various studies have been aimed at introducing the priming effect in $\mathrm{C}$ dynamics models (Guenet et al. 2013; Perveen et al. 2014). An equation describing the soil $\mathrm{OM}$ mineralisation rate as a function of the fresh OM content, proposed by Wutzler and Reichstein (2008) and adapted by Guenet et al. (2013), was introduced in the ORCHIDEE model. This function actually improved the performance of the model for representing incubation data from laboratory experiments. Simulations based on various scenarios highlighted that soil storage capacities predicted by the two versions of the model could differ by up to $12 \mathrm{GtC}$ (i.e. $0.8 \mathrm{tC} \mathrm{ha}^{-1}$ ) for the twenty-first century (Guenet et al. submitted).

The explicit representation of all sequestration mechanisms in Earth-system models is not yet possible since it would necessitate excessively long calculation times and since the equations needed to describe many mechanisms have yet to be accurately formulated. They could however be quickly improved by increasing the number of comparisons between statistical and mechanistic models and by testing the mechanistic models on databases that exist or are under development.

However, the lack of precise data still hampers the use and improvement of models, especially at large spatial scales and in the vertical profile (Mathieu et al. 2015; He et al. 2016 ; Balesdent et al., in press). There are indeed very strong uncertainties with regard to $\mathrm{C}$ stock estimates and the input data of these models (soil parameters, land use, $\mathrm{C}$ inputs, etc.). The progress achieved in the GlobalSoilMap project in developing well-resolved global maps of soil characteristics (Arrouays et al. 2014) is also essential for improving the representation of sequestration mechanisms in Earth-system models.

\subsection{Modelling OM mineralisation at the micro-scale could help describing macroscopic $\mathrm{C}$ fluxes}

Another approach is to precisely describe soil OM mineralisation in micro-scale models and investigate how these models could usefully fuel $\mathrm{C}$ dynamics models operating at larger scales (plot, landscape, global). For example, a few models have emerged during the past decade, explicitly describing the functioning of soil microorganisms in interaction with their substrates, their environment and soil OM (Schimel and Weintraub 2003; Fontaine and Barot 2005; Moorhead and Sinsabaugh 2006; Allison 2012). Some of these models include the representation of several functional groups of microorganisms (e.g. copiotrophic and oligotrophic categories) with homogeneous ecological functioning features. These new models including microbial processes are more consistent with the actual processes and can be more generally applied for various environmental situations. However, they are more complex, often theoretical and not calibrated (Guisan and Zimmermann 2000). One current challenge is to improve their predictive accuracy by testing them on suitable experimental observations (Schmidt et al. 2011). This requires research conducted on various scales (populations, communities, ecosystems) to (1) prioritize key factors for predicting soil $\mathrm{C}$ dynamics and interactions with nutrient cycles, and (2) integrate robust and simplified functions in larger scale models.

A new generation of mechanistic models has also emerged that take the effects of the soil physical structure on the activity of decomposers and on $\mathrm{C}$ mineralisation into account. These models include an explicit 2D or 3D description of the pore network based on computer tomography images (Monga et al. 2008, 2014; Falconer et al. 2007, 2015; Pajor et al. 2010; Resat et al. 2012; Vogel et al. 2015). They operate over short time scales and have been validated for simplified systems. These models should facilitate the classification of variables controlling $\mathrm{C}$ dynamics in order to define soil structure descriptors other than those currently used in models at the plot scale so as to improve them.

An effective strategy could be to use emerging properties from micro-scale models that explicitly take fine-scale soil heterogeneity into account to fuel ecosystem models. Otherwise, simplified versions of fine-scale models that capture fine-scale soil heterogeneity could be designed and integrated in ecosystem models. However, such upscaling from micrometre to plot and then global scales is a difficult task spanning a vast field of research.

\subsection{Data needed to constrain various approaches to enhance prediction of soil C stock evolution patterns}

Irrespective of the approach used to connect the stabilisation mechanisms to the evolution of soil C stocks, the predictions must be compared to field data. Changes in $\mathrm{C}$ stocks are hard to detect in the short term $(<10$ years $)$, which is a methodological challenge for the implementation of the 4 per 1000 programme. The detection of changes in soil $\mathrm{C}$ stocks currently involves repeated analyses over time in long-term field studies (Fornara et al. 2011) or chronosequences (Pöplau et al. 2011). In addition, to assess whether predictions of a particular approach could be generalised, it would be useful to compare the predictions to data collected for different plant covers in various soil and climatic contexts. As such, networks of long-term field experiments and soil monitoring programmes mentioned above (Section 3) are particularly useful. For instance, at sites equipped with flux towers, C stocks, soil 
properties and site management history are monitored, in addition to ecosystem to atmosphere gas fluxes. Many such sites have been developed in recent years, and there are currently about 600 worldwide for a variety of ecosystems, thus enabling relevant data synthesis. For example, a recent study evaluated changes in primary production in grasslands according to the nitrogen fertilisation and climate (annual rainfall and temperature) conditions (Gilmanov et al. 2010; Soussana et al. 2010), while also assessing organic $\mathrm{C}$ sequestration in grassland soils according to the nitrogen fertilisation, harvested biomass (agricultural practices) and soil and weather conditions. Other syntheses of data from flux tower sites showed that the $\mathrm{C}$ balances were instead controlled by management practices in young forests and by climate variations in mature forests (Kowalski et al. 2004). Soil organic C storage was found to increase with the number of days of plant growth (Granier et al. 2000).

Another interesting example is the use of Free-Air $\mathrm{CO}_{2}$ Enrichment experimental systems, which artificially increase the atmospheric $\mathrm{CO}_{2}$ concentration. Such experiments have been developed for several years now and have generated essential information on the response of ecosystems to increased atmospheric $\mathrm{CO}_{2}$ concentrations (Ainsworth and Long 2005). Regarding the soil, they have shown that $\mathrm{C}$ stock increases when nitrogen is available and does not vary when nitrogen is limiting, despite increased input via litter production (Hungate et al. 2009). These data were compared with large-scale model outputs for different output variables (Walker et al. 2015).

Networks of sites thus enable us to estimate the importance of stabilisation mechanisms for $\mathrm{C}$ storage, to classify them (by exploring databases) and to validate approaches designed to improve prediction of soil $\mathrm{C}$ stock evolutionary patterns. However, changes in soil $\mathrm{C}$ stocks are often not observable for several years after a change - this key factor highlights the fact that such sites must absolutely be maintained in the long term.

In conclusion, enhanced integration of soil $\mathrm{OM}$ stabilisation mechanisms in models to improve predictions of the evolution of soil C stocks is not easy. Several approaches could be proposed, each with their positive and negative features. Building soil $\mathrm{C}$ storage indicators based on mechanisms is the simplest approach, but they may have very limited predictive value if they have a weak scientific basis due to the excessive uncertainty level. Finding a suitable and robust formalism to incorporate the mechanisms in large-scale models is often a major research challenge in itself. Linking stabilisation mechanisms and modelling of soil $\mathrm{C}$ stock dynamics requires collaboration of scientific communities conducting research on mechanisms and modelling - this is the only way to accurately assess medium- and long-term variations in soil organic $\mathrm{C}$ stocks in a changing environment.

\section{Conclusion}

The currently favoured solution of the 4 per 1000 initiative to increase soil C stocks is to increase soil C input fluxes through management practices adapted to local conditions. These practices not only influence soil $\mathrm{C}$ inputs but also soil $\mathrm{C}$ stabilisation and destabilisation mechanisms and therefore soil C outputs.

Recent studies have improved the overall understanding of biotic and abiotic mechanisms involved in soil organic $\mathrm{C}$ stabilisation/destabilisation. Belowground plant contributions have a major role in soil $\mathrm{C}$ storage/destocking. Contrary to aboveground litter that might be quickly mineralised, root inputs could greatly contribute to $\mathrm{C}$ inputs that may be stabilised in soils, although they may also induce overmineralisation of native $\mathrm{OM}$, especially when nutrient resources are limited. Plant residues supply intermediate and labile soil $\mathrm{C}$ pools, and, through their chemical composition, control their dynamics. They also indirectly act on the stable $\mathrm{C}$ pool by promoting aggregate formation through roots and mycorrhizal associations. Microorganisms and soil fauna have a central role in soil $\mathrm{C}$ storage/destocking mechanisms because they consume and transform OM. Their metabolic activity produces $\mathrm{CO}_{2}$ and $\mathrm{CH}_{4}$ (destocking) when they consume applied (exogenous) and native (endogenous) OM. However, the action of soil organisms is generally considered to produce secondary compounds that ultimately contribute to soil C stabilisation, either via their chemical recalcitrance or via the interactions they establish with mineral soil ions and surfaces. Soil organisms are also essential for nutrient recycling, and preserving ecosystem balance and biodiversity. All of these co-benefits tend to indicate that soils with high biological activity have a higher $\mathrm{C}$ storage potential. However, their management requires increased knowledge on the interacting mechanisms and is more operationally difficult. The 4 per 1000 initiative will have to consider these antagonist biotic mechanisms in its recommendations in order to balance higher soil $\mathrm{C}$ stabilization with respect to $\mathrm{C}$ mineralisation.

The action of decomposers on $\mathrm{OM}$ depends on the arrangement between particles (inorganic and organic) and on the network of pores in which the fluids, decomposers and their enzymes circulate. Recent studies have also highlighted the central role of mineral phases in protecting OM. However, it appears that all mineral surfaces do not have the same ability to protect organic compounds and that organomineral complexes evolve over time due to weathering processes. Recently developed tools should lead to significant progress in the understanding and modelling of the influence of the soil matrix structure on soil C storage/destocking.

The effects of OM stabilisation mechanisms must be studied throughout the soil profile, including deep soil horizons (up to parent material), since plant root systems have a very high impact. C dynamics models should 
therefore not be limited to the soil surface since deep soils are also impacted by agricultural practices and land-use patterns. These models should try to find indicators that explicitly take the different soil compartments into account and no longer consider the microbial component as a 'black box', while also considering the soil fauna. Research on the validation of indicators of these mechanisms is essential in order to take the complexity of the equation involving biological factors, physical interactions, soil and climate conditions, land-use patterns, practices and management into account.

This review highlighted three essential needs for future research on soil C storage: long-term monitoring of experimental sites; reliable and precisely resolved data (soil parameters, landuse patterns and practices), particularly at large spatial scales; and multidisciplinary interactions between researchers in the fields of soil science and ecology. Indeed, although the different mechanisms are often studied separately, they should be studied together as they are related. These complex interactions drive $\mathrm{C}$ dynamics. Finally, it is crucial to strengthen interactions between operational and academic communities in order to accurately identify the challenges that still need to be addressed to enhance the overall understanding of the impact of agricultural practices on soil C storage, to disseminate new knowledge and translate it into practical recommendations.

Acknowledgments The authors thank all participants of the CarboSMS network meeting of 10 March 2016. We also thank everyone we interviewed on the links between practices and mechanisms (Manuel Blouin, Camille Bréal, Aurélie Cambou, Patrice Cannavo, Marie Castagnet, Annie Duparque, Sabine Houot, Thomas Lerch, Dominique Masse, Anne-Sophie Perrin, Noémie Pousse, Thomas Turini and Laure Vidal-Beaudet). This review was conducted with the financial support of ResMO (French research network on organic matter), ENS-PSL, the Geoscience Department of ENS, CNRS INSU, INRA, ANR-Dedycas and ANR-Soil $\mu 3 \mathrm{D}$. GTF and CR were supported by the EC2COMULTIVERS project (BIOHEFECT-MICROBIEN program, CNRSINSU). We also thank Dr. Eric Lichtfouse (Springer) and Dr. Dominique Arrouays (Etude et Gestion des Sols) for authorising us to submit this English version of the article already published in French in Etude et Gestion des Sols (Derrien et al. 2016).

\section{References}

Ainsworth E, Long SP (2005) What have we learned from 15 years of free air $\mathrm{CO}_{2}$ enrichment (FACE)? A meta-analytic review of the responses of photosynthesis, canopy properties and plant production to rising $\mathrm{CO}_{2}$. New Phytol 165:351-371. doi:10.1111/j.1469-8137. 2004.01224.x

Allison SD (2012) A trait-based approach for modelling microbial litter decomposition. Ecol Lett 15:1058-1070. doi:10.1111/j.1461-0248. 2012.01807.x

Allison SD, Wallenstein MD, Bradford MA (2010) Soil-carbon response to warming dependent on microbial physiology. Nat Geosci 3:336340. doi:10.1038/ngeo846

Amelung W, Brodowski S, Sandhage-Hofmann A, Bol R (2008) Combining biomarker with stable isotope analyses for assessing the transformation and turnover of soil organic matter. In: Advances in agronomy. Academic Press, Burlington, pp 155-250. doi:10.1016/S0065-2113(08)00606-8

Andreetta A, Dignac M-F, Carnicelli S (2013) Biological and physicochemical processes influence cutin and suberin biomarker distribution in two Mediterranean forest soil profiles. Biogeochemistry 112: 41-58. doi:10.1007/s10533-011-9693-9

Andrew C-D, Samuel A, Simon J, Margaret ST (2013) Heterogeneous global crop yield response to biochar: a meta-regression analysis. Environmental Research Letter 8:44 49. doi:10.1088/1748-9326/8/ 4/044049

Angers DA, Arrouays D, Saby NPA, Walter C (2011) Estimating and mapping the carbon saturation deficit of French agricultural topsoils. Soil Use Manag 27:448-552. doi:10.1111/j.1475-2743.2011.00366.x

Armas-Herrera CM, Dignac M-F, Rumpel C, Arbelo CD, Chabbi A (2016) Management effects on composition and dynamics of cutin and suberin in topsoil under agricultural use. Eur J Soil Sci 67:360 373. doi:10.1111/ejss. 12328

Arrouays D (1994) Intérêt du fractionnement densimétrique des matières organiques en vue de la construction d'un modèle bicompartimental d'évolution des stocks de carbone du sol. Exemple après défrichement et monoculture de maïs grain des sols de touyas. Comptes Rendus à l'Académie des Sciences, Paris, série II 318: 787-793

Arrouays D, Grundy MG, Hartemink AE, Hempel JW, Heuvelink GBM, Hong SY, Lagacherie P, Lelyk G, McBratney AB, McKenzie NJ, Mendonca-Santos ML, Minasny B, Montanarella L, IOA O, Sanchez PA, Thompson JA, Zhang G-L (2014) GlobalSoilMap: toward a fine-resolution global grid of soil properties. Adv Agron 125:93-134. doi:10.1016/B978-0-12-800137-0.00003-0

Attard E, Le Roux X, Charrier X, Delfosse O, Guillaumaud N, Lemaire G, Recous S (2016) Delayed and asymmetric responses of soil C pools and $\mathrm{N}$ fluxes to grassland/cropland conversions. Soil Biol Biochem 97:31-39. doi:10.1016/j.soilbio.2016.02.016

Augusto L, De Schrijver A, Vesterdal L, Smolander A, Prescott C, Ranger J (2015) Influences of evergreen gymnosperm and deciduous angiosperm tree species on the functioning of temperate and boreal forests. Biol Rev 90:444-466. doi:10.1111/brv.12119

Balesdent J (1996) The significance of organic separates to carbon dynamics and its modelling in some cultivated soils. Eur J Soil Sci 47: 485-493. doi:10.1111/j.1365-2389.1996.tb01848.x

Balesdent J, Arrouays D (1999) Usage des terres et stockage de carbone dans les sols du territoire français. Une estimation des flux nets annuels pour la période 1900-1999. Comptes Rendus de l'Académie d'Agriculture de. France 85(6):265-277

Balesdent J, Balabane M (1996) Major contribution of roots to soil carbon storage inferred from maize cultivated soils. Soil Biol Biochem 28: 1261-1263. doi:10.1016/0038-0717(96)00112-5

Balesdent J, Chenu C, Balabane M (2000) Relationship of soil organic matter dynamics to physical protection and tillage. Soil Tillage Res 53:215-230. doi:10.1016/S0167-1987(99)00107-5

Balesdent J, Derrien D, Fontaine S, Kirman S, Klumpp K, Loiseau P, Marol C, Nguyen C, Péan M, Personi E, Robin C (2011) Contribution de la rhizodéposition aux matières organiques du sol, quelques implications pour la modélisation de la dynamique du carbone. Etude et Gestion des Sols 18:201-216

Balesdent J, Basile-Doelsch I, Chadoeuf J, Cornu S, Fekiacova et Z, Fontaine S, Guenet B, Hatté C (in press) Renouvellement du carbone profond des sols cultivés: une estimation par compilation de données isotopiques. Biotechnologie Agronomie Société et Environnement

Bardgett RD (2005) The biology of soil: a community and ecosystem approach. OUP Oxford, $256 \mathrm{p}$

Barré P, Plante AF, Cécillon L, Lutfalla S, Baudin F, Bernard S, Christensen BT, Eglin T, Fernandez JM, Houot S, Kätterer T, Le Guillou C, Macdonald A, van Oort F, Chenu C (2016) The energetic 
and chemical signatures of persistent soil organic matter. Biogeochemistry 130:1-12. doi:10.1007/s10533-016-0246-0

Barré P, Durand H, Chenu C, Meunier P, Montagne D, Castel G, Billiou D, Soucémarianadin L, Cécillon L (2017) Geological control of soil organic carbon and nitrogen stocks at the landscape scale. Geoderma 285:50-56. doi:10.1016/j.geoderma.2016.09.029

Basile-Doelsch I, Amundson R, Stone W, Masiello C, Bottero J, Colin F, Masin F, Borschneck D, Meunier JD (2005) Mineral control of soil organic carbon dynamic in an allophanic soil (La Réunion). Eur J Soil Sci 56:689-703. doi:10.1111/j.1365-2389.2005.00703.x

Basile-Doelsch I, Balesdent J, Rose J (2015) Are interactions between organic compounds and nanoscale weathering minerals the key drivers of carbon storage in soils? Environ Sci Technol 49:39973998. doi:10.1021/acs.est.5b00650

Baumann K, Dignac M-F, Rumpel C, Bardoux G, Sarr A, Steffens M, Maron PA (2013) Soil microbial diversity affects soil organic matter decomposition in a silty grassland soil. Biogeochemistry 114:1-3. doi:10.1007/s10533-012-9800-6

Beijerinck MW (1913) De infusies en de ontdekking der bakterien. In: Jaarboek van de Koninklijke Akademie van Wetenschappen (F Müller, Amsterdam), pp 1-28

Bell T, Newman JA, Silverman BW, Turner SL, Lilley AK (2005) The contribution of species richness and composition to bacterial services. Nature 436:1157-1160. doi:10.1038/nature03891

Beniston JW, DuPont ST, Glover JD, Lal R, Dungait JAJ (2014) Soil organic carbon dynamics 75 years after land-use change in perennial grassland and annual wheat agricultural systems. Biogeochemistry 120:37-49. doi:10.1007/s10533-014-9980-3

Berg B (2014) Decomposition patterns for foliar litter - a theory for influencing factors. Soil Biol Biochem 78:222-232. doi:10.1016/j. soilbio.2014.08.005

Berg B, Ekbohm G (1991) Litter mass-loss rates and decomposition patterns in some needle and leaf litter types. Long-term decomposition in a scots pine forest VII. Can J Bot 69:1449-1456. doi:10. 1139/b91-187

Berg B, Davey MP, De Marco A, Emmett B, Faituri M, Hobbie SE, Johansson MB, Liu C, McClaugherty C, Norell L, Rutigliano FA, Vesterdal L, De Santo AV (2010) Factors influencing limit values for pine needle litter decomposition: a synthesis for boreal and temperate pine forest systems. Biogeochemistry 100:57-73. doi:10.1007/ s10533-009-9404-y

Besnard E, Chenu C, Balesdent J, Puget P, Arrouays D (1996) Fate of particulate organic matter in soil aggregates during cultivation. Eur $\mathrm{J}$ Soil Sci 47:495-503. doi:10.1111/j.1365-2389.1996.tb01849.x

Birouste M, Kazakou E, Blanchard A, Roumet C (2012) Plant traits and decomposition: are the relationships for roots comparable to those for leaves? Ann Bot 109:463-472. doi:10.1093/aob/mcr297

Blagodatskaya E, Kuzyakov Y (2008) Mechanisms of real and apparent priming effects and their dependence on soil microbial biomass and community structure: critical review. Biol Fertil Soils 45:115-131. doi:10.1007/s00374-008-0334-y

Bohlen JP, Pelletier MD, Groffman MP, Fahey JT, Fisk CM (2004) Influence of earthworm invasion on redistribution and retention of soil carbon and nitrogen in northern temperate forests. Ecosystems 7:13-27. doi:10.1007/s10021-003-0127-y

Bonkowski M (2004) Protozoa and plant growth: the microbial loop in soil revisited. New Phytol 162:617-631. doi:10.1111/j.1469-8137. 2004.01066.x

Bonneville S, Morgan DJ, Schmalenberger A, Bray A, Brown A, Banwart SA, Benning LG (2011) Tree-mycorrhiza symbiosis accelerate mineral weathering: evidences from nanometer-scale elemental fluxes at the hypha-mineral interface. Geochim Cosmochim Acta 75:6988-7005. doi:10.1016/j.gca.2011.08.041

Bossuyt H, Six J, Hendrix PF (2004) Rapid incorporation of carbon from fresh residues into newly formed stable microaggregates within earthworm casts. Eur J Soil Sci 55:393-399. doi:10.1111/j.13510754.2004.00603.x

Bossuyt H, Six J, Hendrix PF (2005) Protection of soil carbon by microaggregates within earthworm casts. Soil Biol Biochem 37: 251-258. doi:10.1016/j.soilbio.2004.07.035

Brauman A (2000) Effect of gut transit and mound deposit on soil organic matter transformations in the soil feeding termite: a review. Eur $\mathrm{J}$ Soil Biol 36:117-125. doi:10.1016/S1164-5563(00)01058-X

Brown GG (1995) How do earthworms affect microfloral and faunal community diversity. Plant Soil 170:209-231. doi:10.1007/ BF02183068

Bruun TB, Elberling B, Christensen BT (2010) Lability of soil organic carbon in tropical soils with different clay minerals. Soil Biol Biochem 42:888-895. doi:10.1016/j.soilbio.2010.01.009

Cardinael R, Chevallier T, Barthès B, Saby N, Parent T, Dupraz C, Bernoux M, Chenu C (2015) Impact of alley cropping agroforestry on stocks, forms and spatial distribution of soil organic carbon - a case study in a Mediterranean context. Geoderma 259-260:288299. doi:10.1016/j.geoderma.2015.06.015

Chapuis-Lardy L, Brauman A, Bernard L, Pablo AL, Toucet J, Mano MJ, Weber L, Brunet D, Razafimbelo T, Chotte JL, Blanchart E (2010) Effect of the endogeic earthworm Pontoscolex corethrurus on the microbial structure and activity related to $\mathrm{CO}_{2}$ and $\mathrm{N}_{2} \mathrm{O}$ fluxes from a tropical soil (Madagascar). Appl Soil Ecol 45:201-208. doi:10. 1016/j.apsoil.2010.04.006

Chenu C, Plante AF (2006) Clay-sized organo-mineral complexes in a cultivation chronosequence: revisiting the concept of the 'primary organo-mineral complex'. Eur J Soil Sci 57:596-607. doi:10.1111/j. 1365-2389.2006.00834.x

Chenu C, Stotzky G (2002) Interactions between microorganisms and soil particles: an overview. In: Huang PM, Bollag JM, Senesi N (eds) Interactions between soil particles and microorganisms. Wiley and Sons, New York, pp 3-40

Chenu C, Garnier P, Monga O, Moyano F, Pot V, Nunan N, Otten W (2014a) Predicting the response of soil organic matter microbial decomposition to moisture. Geophys Res Abstr 16:EGU2014 EG14981

Chenu C, Klumpp K, Bispo A, Angers D, Colnenne C, Metay A (2014b) Stocker du carbone dans les sols agricoles: évaluation de leviers d'action pour la France. Innovations Agronomiques 37:23-37

Chevallier T, Voltz M, Blanchart E, Chotte J-L, Eschenbrenner V, Mahieu M, Albrecht A (2000) Spatial and temporal changes of soil C after establishment of a pasture on a long-term cultivated vertisol (Martinique). Geoderma 94:43-58. doi:10.1016/S0016-7061(99) 00064-6

Chevallier T, Blanchart E, Girardin C, Mariotti A, Albrecht A, Feller C (2001) The role of biological activity (roots, earthworms) in medium-term $\mathrm{C}$ dynamics in vertisol under a Digitaria decumbens (Gramineae) pasture. Appl Soil Ecol 16:11-21. doi:10.1016/S09291393(00)00102-5

Chevallier T, Blanchart E, Albrecht A, Feller C (2004) The physical protection of soil organic carbon in aggregates: a mechanism of carbon storage in a vertisol under pasture and market gardening (Martinique, West Indies). Agric Ecosyst Environ 103:375-387. doi:10.1016/j.agee.2003.12.009

Chevallier T, Woignier T, Toucet J, Blanchart E (2010) Organic carbon stabilization in the fractal pore structure of andosols. Geoderma 159: 182-188. doi:10.1016/j.geoderma.2010.07.010

Chotte J-L, Diouf M, Assigbetse K, Lesueur D, Rabary B, Sall S (2013) Unexpected similar stability of soil microbial $\mathrm{CO}_{2}$ respiration in 20year manured and in unmanured tropical soils. Environ Chem Lett 11:135-142. doi:10.1007/s10311-012-0388-9

Clemmensen KE, Bahr A, Ovaskainen O, Dahlberg A, Ekblad A, Wallander H, Stenlid J, Finlay RD, Wardle DA, Lindahl BD (2013) Roots and associated fungi drive long-term carbon 
sequestration in boreal forest. Science 339:1615-1618. doi:10.1126/ science. 1231923

Clemmensen KE, Finlay RD, Dahlberg A, Stenlid J, Wardle DA, Lindahl BD (2015) Carbon sequestration is related to mycorrhizal fungal community shifts during long-term succession in boreal forests. New Phytol 205:1525-1536. doi:10.1111/nph.13208

Conant RT, Paustian K, Elliott ET (2001) Grassland management and conversion into grassland: effects on soil carbon. Ecol Appl 11:343-355. doi:10.1890/1051-0761(2001)011[0343:GMACIG]2.0.CO;2

Cotrufo MF, Soong JL, Horton AJ, Campbell EE, Haddix M, Wall DH, Parton AJ (2015) Formation of soil organic matter via biochemical and physical pathways of litter mass loss. Nat Geosci 8:776-780. doi:10.1038/ngeo2520

Craine JM, Wedin DA, Chapin FS, Reich PB (2003) Relationship between the structure of root systems and resource use for 11 North American grassland plants. Plant Ecol 165:85-100. doi:10.1023/A: 1021414615001

Crow SE, Swanston CW, Lajtha K, Brooks JR, Keirstead H (2007) Density fractionation of forest soils: methodological questions and interpretation of incubation results and turnover time in an ecosystem context. Biogeochemistry 85:69-90. doi:10.1007/s10533-007-9100-8

Curtis TP, Sloan WT (2005) Exploring microbial diversity - a vast below. Science 309:1331-1333. doi:10.1126/science.1118176

Decaëns T, Galvis JH, Amezquita E (2001) Properties of the structures created by ecological engineers at the soil surface of a Colombian savanna. Comptes Rendus de l'Académie des Sciences de Paris Série III-Sciences de la Vie 324:465-477. doi:10.1016/S07644469(01)01313-0

Derrien D, Dignac M-F, Basile-Doelsch I, Barot S, Cécillon L, Chenu C, Chevallier T, Freschet GT, Garnier P, Guenet B, Hedde M, Klumpp K, Lashermes G, Maron P-A, Nunan N, Roumet C, Barré P (2016) Stocker du C dans les sols : Quels mécanismes, quelles pratiques agricoles, quels indicateurs ? Etude et Gestion des Sols 23:193-223

Derrien D, Marol C, Balabane M, Balesdent J (2006) The turnover of carbohydrates in a cultivated soil estimated by ${ }^{13} \mathrm{C}$ natural abundances. Eur J Soil Sci 57:547-557. doi:10.1111/j.1365-2389.2006. 00811.x

Derrien D, Plain C, Courty P-E, Gelhaye L, Moerdijk-Poortvliet TCW, Thomas F, Versini A, Zeller B, Koutika LS, Boschker HTS, Epron D (2014) Does the addition of labile substrate destabilise old soil organic matter? Soil Biol Biochem 76:149-160. doi:10.1016/j.soilbio. 2014.04.030

Dignac M-F, Kögel-Knabner I, Michel K, Matzner E, Knicker H (2002) Chemistry of soil organic matter as related to $\mathrm{C} / \mathrm{N}$ in Norway spruce forest (Picea abies (L) karst.) floors and mineral soils. J Plant Nutr Soil Sci 165:281-289. doi:10.1002/1522-2624(200206)165: 3<281::AID-JPLN281>3.0.CO;2-A

Dimassi B, Mary B, Wylleman R, Labreuche J, Couture D, Piraux F, Cohan JP (2014) Long-term effect of contrasted tillage and crop management on soil carbon dynamics during 41 years. Agric Ecosyst Environ 188:134-146. doi:10.1016/j.agee.2014.02.014

Don A, Steinberg B, Schöning I, Pritsch K, Joschko M, Gleixner G, Schulze E-D (2008) Organic carbon sequestration in earthworm burrows. Soil Biol Biochem 40:1803-1812. doi:10.1016/j.soilbio. 2008.03.003

Don A, Riedenbeck C, Gleixner G (2013) Unexpected control of soil carbon turnover by soil carbon concentration. Environ Chem Lett 11:407-413. doi:10.1007/s10311-013-0433-3

Dungait JAJ, Hopkins DW, Gregory AS, Whitmore AP (2012) Soil organic matter turnover is governed by accessibility not recalcitrance. Glob Chang Biol 18:1781-2088. doi:10.1111/j.1365-2486.2012. 02665.x

DuPont ST, Beniston J, Glover JD, Hodson A, Culman SW, Lal R, Ferris $\mathrm{H}$ (2014) Root traits and soil properties in harvested perennial grassland, annual wheat, and never-tilled annual wheat. Plant Soil 381: 405-420. doi:10.1007/s11104-014-2145-2
Edmondson JI, Davies ZG, McHugh N, Gaston KJ, Leake JR (2012) Organic carbon hidden in urban ecosystems. Scientific Reports. doi:10.1038/srep00963

Eglin T, Ciais P, Piao SL, Barre P, Bellassen V, Cadule P, Chenu C, Gasser T, Koven C, Reichstein M, Smith P (2010) Historical and future perspectives of global soil carbon response to climate and land-use changes. Tellus-B 62:700-718. doi:10.1111/j.1600-0889.2010. 00499.x

Erktan A, Cécillon L, GrafF, Roumet C, Legout C, Rey F (2016) Increase in soil aggregate stability along a Mediterranean successional gradient in severely eroded gully bed ecosystems: combined effects of soil, root traits and plant community characteristics. Plant Soil 398: 121-137. doi:10.1007/s11104-015-2647-6

Etema C, Wardle DA (2002) Spatial soil ecology. Trends Ecol Evol 17: 177-183. doi:10.1016/S0169-5347(02)02496-5

Falconer RE, Bown JL, White NA, Crawford JW (2007) Biomass recycling: a key to efficient foraging by fungal colonies. Oikos 116:1558-1568. doi:10.1111/j.0030-1299.2007.15885.x

Falconer RE, Battaia G, Schmidt S, Baveye P, Chenu C, Otten W (2015) Microscale heterogeneity explains experimental variability and nonlinearity in soil organic matter mineralisation. PLoS One 10:1-12. doi:10.1371/journal.pone. 0123774

Feller C, Chenu C (2012) Les inter-actions bio-organo-argileuses et la stabilisation du carbone dans les sols. Etude et Gestion des Sols 19: 235-248

Fernandez CW, Kennedy PG (2015) Moving beyond the black-box: fungal traits, community structure, and carbon sequestration in forest soils. New Phytol 205:1378-1380. doi:10.1111/nph.13289

Fernandez CW, Langley JA, Chapman S, McCormack ML, Koide RT (2016) The decomposition of ectomycorrhizal fungal necromass. Soil Biol Biochem 93:38-49. doi:10.1016/j.soilbio.2015.10.017

Fontaine S, Barot S (2005) Size and functional diversity of microbe populations control plant persistence and long-term soil carbon accumulation. Ecol Lett 8:1075-1087. doi:10.1111/j.1461-0248.2005. 00813.x

Fontaine S, Bardoux G, Benest D, Verdier B, Mariotti A, Abbadie L (2004) Carbon input to soil may decrease soil carbon content. Ecol Lett 7:314-320. doi:10.1111/j.1461-0248.2004.00579.x

Fontaine S, Barot S, Barré P, Bdioui N, Mary B, Rumpel C (2007) Stability of organic carbon in deep soil layers controlled by fresh carbon supply. Nature 450:277-280. doi:10.1038/nature06275

Fontaine S, Henault C, Aamor A, Bdioui N, Bloor JMG, Maire V, Mary B, Revaillot S, Maron PA (2011) Fungi mediate long term sequestration of carbon and nitrogen in soil through their priming effect. Soil Biol Biochem 43:86-96. doi:10.1016/j.soilbio.2010.09.017

Fornara DA, Steinbeiss S, McNamara NP, Gleixner G, Oakley S, Poulton PR, Macdonald AJ, Bardgett RD (2011) Increases in soil organic carbon sequestration can reduce the global warming potential of liming to permanent grassland. Glob Chang Biol 17:1925-1934. doi:10.1111/j.1365-2486.2010.02328.x

Freschet G, Masse D, Hien E, Sall S, Chotte JL (2008) Long-term changes in organic matter and microbial properties resulting from manuring practices in an arid cultivated soil in Burkina Faso. Agric Ecosyst Environ 123:175-184. doi:10.1016/j.agee.2007.05.012

Freschet GT, Cornwell WK, Wardle DA, Elumeeva TG, Liu W, Jackson BG, Onipchenko VG, Soudzilovskaia NA, Tao JP, Cornelissen JHC (2013) Linking litter decomposition of above and belowground organs to plant-soil feedbacks worldwide. J Ecol 101:943-952. doi: 10.1111/1365-2745.12092

Freschet GT, Violle, Roumet C, Garnier E (in press). Interactions entre le sol et la végétation: structure des communautés de plantes et fonctionnement du sol. In: Lemanceau P \& Blouin M (Eds) Les sols au coeur de la zone critique: Ecologie

Friedlingstein P, Cox P, Betts R, Bopp L, Von Bloh W, Brovkin V, Cadule P, Doney S, Eby M, Fung I, Bala G, John J, Jones C, Joos F, Kato T, Kawamiya M, Knorr W, Lindsay K, Matthews HD, Raddatz T, 
Rayner P, Reick C, Roeckner E, Schnitzler KG, Schnur R, Strassmann K, Weaver AJ, Yoshikawa C, Zeng N (2006) Climatecarbon cycle feedback analysis: results from the $\mathrm{C}^{4} \mathrm{MIP}$ model intercomparison. J Clim 19:3337-3353. doi:10.1175/JCLI3800.1

Gans J, Wolinsky M, Dunbar J (2005) Computational improvements reveal great bacterial diversity and high metal toxicity in soil. Science 309:1387-1390. doi:10.1126/science.1112665

Garcia-Pausas J, Casals P, Rovira P, Vallecillo S, Sebastià M-T, Romanyà J (2012) Decomposition of labelled roots and root-C and -N allocation between soil fractions in mountain grasslands. Soil Biol Biochem 49:61-69. doi:10.1016/j.soilbio.2012.02.015

Gardi C, Montanarella L, Arrouays D, Bispo A, Lemanceau P, Jolivet C, Mulder C, Ranjard L, Rombke J, Rutgers M, Menta C (2009) Soil biodiversity monitoring in Europe: ongoing activities and challenges. Eur J Soil Sci 60:807-819. doi:10.1111/j.1365-2389.2009.01177.x

Garten CT (2009) A disconnect between O horizon and mineral soil carbon-implications for soil C sequestration. Acta Oecol 35:218 226. doi:10.1016/j.actao.2008.10.004

Geyer KM, Kyker-Snowman E, Grandy AS, Frey SD (2016) Microbial carbon use efficiency: accounting for population, community, and ecosystem-scale controls over the fate of metabolized organic matter. Biogeochemistry 127:173-188. doi:10.1007/s10533-016-0191-y

Gignoux J, House J, Hall D, Masse D, Nacro HB, Abbadie L (2001) Design and test of a generic cohort model of soil organic matter decomposition: the SOMKO model. Glob Ecol Biogeogr 10:639-660

Gilmanov TG, Aires L, Barcza Z, Baron VS, Belelli L, Beringer J, Billesbach D, Bonal D, Bradford J, Ceschia E, Cook D, Corradi C, Frank A, Gianelle D, Gimeno C, Gruenwald T, Guo HQ, Hanan N, Haszpra L, Heilman J, Jacobs A, Jones MB, Johnson DA, Kiely G, Li SG, Magliulo V, Moors E, Nagy Z, Nasyrov M, Owensby C, Pinter K, Pio C, Reichstein M, Sanz MJ, Scott R, Soussana J-F, Stoy PC, Svejcar T, Tuba Z, Zhou GS (2010) Productivity, respiration, and light-response parameters of world grassland and agroecosystems derived from flux-tower measurements. Rangel Ecol Manag 63:16-39. doi:10.1046/j.1466-822X. 2001.t01-1-00250.x

Golchin A, Oades JM, Skjemstad JO, Clarke P (1994) Soil structure and carbon cycling. Aust J Soil Res 32:1043-1068. doi:10.1071/ SR9941043

Granier A, Ceschia E, Damesin C, Dufrene E, Epron D, Gross P, Lebaube S, Le Dantec V, Le Goff N, Lemoine D, Lucot E, Ottorini J-M, Pontailler J-Y, Saugier B (2000) The carbon balance of a young beech forest. Funct Ecol 14:312-325. doi:10.1046/j.1365-2435. 2000.00434.x

Griffiths BS, Ritz K, Wheatley R, Kuan HL, Boag B, Christensen S, Ekelund F, Sorensen SJ, Muller S, Bloem J (2001) An examination of the biodiversity-ecosystem function relationship in arable soil microbial communities. Soil Biol Biochem 33:1713-1722. doi:10. 1016/S0038-0717(01)00094-3

Griffiths BS, Hallett PD, Kuan HL, Gregory AS, Watts CW, Whitmore AP (2008) Functional resilience of soil microbial communities depends on both soil structure and microbial community composition. Biol Fertil Soils 44:745-754. doi:10.1007/s00374-007-0257-Z

Guenet B, Eglin T, Vasilyeva N, Peylin P, Ciais P, Chenu C (2013) The relative importance of decomposition and transport mechanisms in accounting for soil organic carbon profiles. Biogeosciences 10: 2379-2392. doi:10.5194/bg-10-2379-2013

Guenet B, Camino-Serrano M, Ciais P, Tifafi M, Maignan F, Soong JL, Janssens IA (submitted) Impact of priming on global carbon emissions from soils

Guisan A, Zimmermann NE (2000) Predictive habitat distribution models in ecology. Ecol Model 135:147-186. doi:10.1016/S0304-3800(00) 00354-9

Guo LB, Gifford RM (2002) Soil carbon stocks and land use change: a meta analysis. Glob Chang Biol 8:345-360. doi:10.1046/j.13541013.2002.00486.x
Gyssels G, Poesen J, Bochet E, Li Y (2005) Impact of plant roots on the resistance of soils to erosion by water: a review. Prog Phys Geogr 29:189-217. doi:10.1191/0309133305pp443ra

Haddix ML, Paul EA, Cotrufo MF (2016) Dual, differential isotope labeling shows the preferential movement of labile plant constituents into mineral bonded soil organic matter. Glob Chang Biol 22:23012312. doi: $10.1111 / \mathrm{gcb} .13237$

Han P, Zhang W, Wang G, Sun W, Huang Y (2016) Changes in soil organic carbon in croplands subjected to fertilizer management: a global metaanalysis. Nature Scientific Reports. doi:10.1038/ srep27199

Hargreaves JC, Adl MS, Warman PR (2008) A review of the use of composted municipal solid waste in agriculture. Agric Ecosyst Environ 123:1-14. doi:10.1016/j.agee.2007.07.004

Hassink J (1997) The capacity of soils to preserve organic C and $\mathrm{N}$ by their association with clay and silt particles. Plant Soil 191:77-87. doi:10.1023/A:1004213929699

Hatton P-J, Remusat L, Zeller B, Brewer EA, Derrien D (2015) NanoSIMS investigation of glycine-derived $\mathrm{C}$ and $\mathrm{N}$ retention with soil organo-mineral associations. Biogeochemistry 125:303-313. doi:10.1007/s10533-015-0138-8

Hawksworth DL (1991) The fungal dimension of biodiversity: magnitude, significance, and conservation. Mycol Res 95:641-655. doi: 10.1016/S0953-7562(09)80810-1

He Y, Trumbore SE, Torn MS, Harden JW, Vaughn LJ, Allison SD, Randerson JT (2016) Radiocarbon constraints imply reduced carbon uptake by soils during the 21st century. Science 353:1419-1424. doi:10.1126/science.aad4273

Hedde M, Lavelle P, Joffre R, Jimenez JJ, Decaens T (2005) Specific functional signature in soil macro-invertebrate biostructures. Funct Ecol 19:785-793. doi:10.1111/j.1365-2435.2005.01026.x

van der Heijden MG, Bardgett RD, van Straalen NM (2008) The unseen majority: soil microbes as drivers of plant diversity and productivity in terrestrial ecosystems. Ecol Lett 11:296-310. doi:10.1111/j.14610248.2007.01139.x

Hemkemeyer M, Christensen BT, Martens R, Tebbe CC (2015) Soil particle size fractions harbour distinct microbial communities and differ in potential for microbial mineralisation of organic pollutants. Soil Biol Biochem 90:255-265. doi:10.1016/j.soilbio.2015.08.018

Henin S, Dupuis M (1945) Essai de balance de la matière organique du sol. Annales Agronomiques 1:6-26

Ho A, de Roy K, Thas O, De Neve J, Hoefman S, Vandamme P, Heylen $\mathrm{K}$, Boon N (2014) The more, the merrier: heterotroph richness stimulates methanotrophic activity. ISME J 8:1945-1948. doi:10.1038/ ismej. 2014.74

Hungate BA, van Groeningen K-J, Six J, Jastrow JD, Luo YQ, de Graaff MA, van Kessel C, Osenberg CW (2009) Assessing the effect of elevated carbon dioxide on soil carbon: a comparison of four metaanalyses. Glob Chang Biol 15:2020-2034. doi:10.1111/j.13652486.2009.01866.x

IPCC (2006) Guidelines for national greenhouse gas inventories, prepared by the National Greenhouse Gas Inventories Programme. Eggleston HS, Buendia L, Miwa K, Ngara T and Tanabe K (eds). Published: IGES, Japan

IPCC (2013) Climate change 2013: the physical science basis. Contribution of Working Group I to the Fifth Assessment Report of the Intergovernmental Panel

Jandl R, Lindner M, Vesterdal L, Bauwens B, Baritz R, Hagedorn F, Johnson DW, Minkkinen K, Byrne KA (2006) How strongly can forest management influence soil carbon sequestration? Geoderma 137:253-268. doi:10.1016/j.geoderma.2006.09.003

Janssens IA, Dieleman W, Luyssaert S, Subke JA, Reichstein M, Ceulemans R, Ciais P, Dolman AJ, Grace J, Matteucci G, Papale D, Piao SL, Schulze ED, Tang J, Law BE (2010) Reduction of forest soil respiration in response to nitrogen deposition. Nat Geosci 3: 315-322. doi:10.1038/ngeo844 
Jastrow JD, Amonette JE, Bailey VL (2007) Mechanisms controlling soil carbon turnover and their potential application for enhancing carbon sequestration. Clim Chang 80:5-23. doi:10.1007/s10584-006-9178-3

Jiménez JJ, Decaëns T, Lavelle P (2008) C and N concentrations in biogenic structures of a soil-feeding termite and a fungus-growing ant in the Colombian savannas. Appl Soil Ecol 40:120-128. doi:10. 1016/j.apsoil.2008.03.009

Jobbágy EG, Jackson RB (2000) The vertical distribution of soil organic carbon and its relation to climate and vegetation. Ecol Appl 10:423436. doi:10.1890/1051-0761(2000)010[0423:TVDOSO]2.0.CO;2

Joimel S, Cortet J, Jolivet CC, Saby NPA, Chenot ED, Branchu P, Consalès JN, Lefort C, Schwartz C (2016) Physico-chemical characteristics of topsoil for contrasted forest, agricultural, urban and industrial land uses in France. Sci Total Environ 545:40-47. doi: 10.1016/j.scitotenv.2015.12.035

Jolivet C, Arrouays D, Lévèque J, Andreux F, Chenu C (2003) Organic carbon dynamics in soil particle-size separates of temperate forest Spodosols converted to maize cropping. Eur J Soil Sci 54:257-268. doi:10.1046/j.1365-2389.2003.00541.x

Jonard M, Nicolas M, Coomes DA, Caignet I, Saenger A, Ponette Q (2017) Forest soils in France are sequestering substantial amounts of carbon. Sci Total Environ 574:616-628. doi:10.1016/j.scitotenv. 2016.09.028

Jones DL, Edwards AC (1998) Influence of sorption on the biological utilization of two simple carbon substrates. Soil Biol Biochem 30: 1895-1902. doi:10.1016/S0038-0717(98)00060-1

Jones DL, Nguyen C, Finlay RD (2009) Carbon flow in the rhizosphere: carbon trading at the soil-root interface. Plant Soil 321:5-33. doi:10. 1007/s11104-009-9925-0

Jouquet P, Ngo TP, Nguyen HH, Henry-des-Tureaux T, Chevallier T, Duc TT (2011) Laboratory investigation of organic matter mineralization and nutrient leaching from earthworm casts produced by Amynthas khami. Appl Soil Ecol 47:24-30. doi:10.1016/j.apsoil.2010.11.004

Juarez S, Nunan N, Duday A-C, Pouteau V, Schmidt S, Hapca S, Chenu C (2013) Effects of different soil structures on the decomposition of native and added organic carbon. Eur J Soil Biol 58:81-90. doi:10. 1016/j.ejsobi.2013.06.005

Kawano M, Tomita K (2001) TEM-EDX, study of weathered layers on the surface of volcanic glass, bytownite, and hypersthene in volcanic ash from Sakurajima volcano, Japan. Am Mineral 86:284-292. doi: 10.2138/am-2001-2-311

Keiluweit M, Nico P, Harmon ME, Mao J, Pett-Ridge J, Kleber M (2015a) Long-term litter decomposition controlled by manganese redox cycling. Proceedings of the National Academy of Sciences 112:5253-5260. doi:10.1073/pnas. 1508945112

Keiluweit M, Bougoure JJ, Nico PS, Pett-Ridge J, Weber PK, Kleber M (2015b) Mineral protection of soil carbon counteracted by root exudates. Nat Clim Chang 5:588-595. doi:10.1038/nclimate2580

Khomo L, Trumbore S, Bern C R, Chadwick O A (2016) Timescales of C turnover in soils with mixed crystalline mineralogies, Kruger National Park, South Africa. SOIL Discussions. doi:10.5194/soil2016-31

Killham K, Amato M, Ladd JN (1993) Effect of substrate location in soil and soil pore-water regime on carbon turnover. Soil Biol Biochem 25:57-62. doi:10.1016/0038-0717(93)90241-3

Kleber M, Sollins P, Sutton R (2007) A conceptual model of organomineral interactions in soils: self-assembly of organic molecular fragments into zonal structures on mineral surfaces. Biogeochemistry 85:9-24. doi:10.1007/s10533-007-9103-5

Kleber M, Eusterhues K, Keiluweit M, Mikutta C, Mikutta R, Nico PS (2015) Chapter one - mineral-organic associations: formation, properties, and relevance in soil environments. In: Donald, LS (Ed.), Advances in agronomy. Academic Press, pp 1-140

Köchy M, Hiederer R, Freibauer A (2015) Global distribution of soil organic carbon-part 1: masses and frequency distributions of
SOC stocks for the tropics, permafrost regions, wetlands, and the world. Soil 1:351-365. doi:10.5194/soil-1-351-2015

Kögel-Knabner I, Guggenberger G, Kleber M, Kandeler E, Kalbitz K, Scheu S, Eusterhues K, Leinweber P (2008) Organo-mineral associations in temperate soils: integrating biology, mineralogy, and organic matter chemistry. J Plant Nutr Soil Sci 171:61-82. doi:10. 1002/jpln.200700048

Kowalski AS, Loustau D, Berbigier P, Manca G, Tedeschi V, Borghetti M, Valentini R, Kolari P, Berninger F, Rannik U, Hari P, Rayment M, Mencuccini M, Moncrieff J, Grace J (2004) Paired comparisons of carbon exchange between undisturbed and regenerating stands in four managed forests in Europe. Glob Chang Biol 10:1707-1723. doi:10.1111/j.1365-2486.2004.00846.x

Kulak M, Graves A, Chatterton J (2013) Reducing greenhouse gas emissions with urban agriculture: a life cycle assessment perspective. Landsc Urban Plan 111:68-78. doi:10.1016/j.landurbplan.2012.11. 007

Kuzyakov Y, Domanski G (2000) Carbon input by plants into the soil. Review Journal of Plant Nutrition and Soil Science 163:421-431. doi:10.1002/1522-2624(200008)163:4<421::AID-JPLN421>3.0. $\mathrm{CO} ; 2-\mathrm{R}$

Lal R, Augustin B (Eds.) (2011) Carbon sequestration in urban ecosystems. Springer Science \& Business Media

Lal R, Griffin M, Apt J, Lave L, Morgan MG (2004) Managing soil carbon. Science 304:393. doi:10.1126/science.1093079

Lange M, Eisenhauer N, Sierra CA, Bessler H, Engels C, Griffiths RI, Mellado-Vázquez PG, Malik AA, Roy J, Scheu S, Steinbeiss S, Thomson BC, Trumbore SE, Gleixner G (2015) Plant diversity increases soil microbial activity and soil carbon storage. Nat Commun 6:6707. doi:10.1038/ncomms 7707

Langley JA, Chapman SK, Hungate BA (2006) Ectomycorrhizal colonization slows root decomposition: the post-mortem fungal legacy. Ecol Lett 9:955-959. doi:10.1111/j.1461-0248.2006.00948.x

Lashermes G, Nicolardot B, Parnaudeau V, Thuries L, Chaussod R, Guillotin ML, Lineres M, Mary B, Metzger L, Morvan T, Tricaud A, Villette C, Houot S (2009) Indicator of potential residual carbon in soils after exogenous organic matter application. Eur J Soil Sci 60: 297-310. doi:10.1111/j.1365-2389.2008.01110.x

Lashermes G, Gainvors-Claisse A, Recous S, Bertrand I (2016) Enzymatic strategies and carbon use efficiency of a litterdecomposing fungus grown on maize leaves, stems, and roots. Front Microbiol. doi:10.3389/fmicb.2016.01315

Lavelle P (1997) Faunal activities and soil processes: adaptive strategies that determine ecosystem function. Adv Ecol Res 27:93-132. doi: 10.1016/S0065-2504(08)60007-0

Le Bayon RC, Binet F (2006) Earthworms change the distribution and availability of phosphorous in organic substrates. Soil Biol Biochem 38:235-246. doi:10.1016/j.soilbio.2005.05.013

Le Bissonnais Y, Cerdan O, Lecomte V, Benkhadra H, Souchère V, Martin P (2005) Variability of soil surface characteristics influencing runoff and interrill erosion. Catena 62:111-124. doi:10.1016/j. catena.2005.05.001

Le Quéré C, Moriarty R, Andrew RM, Peters GP, Ciais P, Friedlingstein P, Jones SD, Sitch S, Tans P, Arneth A, Boden TA, Bopp L, Bozec Y, Canadell JG, Chini LP, Chevallier F, Cosca CE, Harris I, Hoppema M, Houghton RA, House JI, Jain AK, Johannessen T, Kato E, Keeling RF, Kitidis V, Goldewijk KK, Koven C, Landa CS, Landschutzer P, Lenton A, Lima ID, Marland G, Mathis JT, Metzl N, Nojiri Y, Olsen A, Ono T, Peng S, Peters W, Pfeil B, Poulter B, Raupach MR, Regnier P, Rodenbeck C, Saito S, Salisbury JE, Schuster U, Schwinger J, Seferian R, Segschneider J, Steinhoff T, Stocker BD, Sutton AJ, Takahashi T, Tilbrook B, van der Werf GR, Viovy N, Wang YP, Wanninkhof R, Wiltshire A, Zeng N (2015) Global carbon budget 2014. Earth System Science Data 7:47-85. doi:10.5194/essd-7-349-2015 
Lehmann J, Kleber M (2015) The contentious nature of soil organic matter. Nature 528:60-68. doi:10.1038/nature16069

Levard C, Doelsch E, Basile-Doelsch I, Abidin Z, Miche H, Masion A, Rose J, Borschneck D, Bottero JY (2012) Structure and distribution of allophanes, imogolite and proto-imogolite in volcanic soils. Geoderma 183-184:100-108. doi:10.1016/j.geoderma.2012.03.015

Li Q, Yu PJ, Li GD, Zhou DW (2016) Grass-legume ratio can change soil carbon and nitrogen storage in a temperate steppe grassland. Soil Tillage Res 157:23-31. doi:10.1016/j.still.2015.08.021

Lienhard P, Terrat S, Mathieu O, Levêque J, Chemidlin Prévost-Bouré N, Nowak V, Régnier T, Faivre C, Sayphoummie S, Panyasiri K, Tivet F, Ranjard L, Maron P-A (2013) Soil microbial diversity and C turnover modified by tillage and cropping in Laos tropical grassland. Environ Chem Lett 11:391-398. doi:10.1007/s10311-013-0420-8

Löhnis F (1926) Nitrogen availability of green manures. Soil Sci 22:253290

Lubbers IM, van Groenigen KJ, Fonte SJ, Six J, Brussaard L, van Groenigen JW (2013) Greenhouse-gas emissions from soils increased by earthworms. Nat Clim Chang 3:1-8. doi:10.1038/ NCLIMATE1692

Luo Z, Wang E, Sun OJ (2010) Can no-tillage stimulate carbon sequestration in agricultural soils? A meta-analysis of paired experiments agriculture. Ecosystems and Environment 139:224-231. doi:10. 1016/j.agee.2010.08.006

Luo Y, Ahlström A, Allison SD, Batjes NH, Brovkin V, Carvalhais N, Chappell A, Ciais P, Davidson EA, Finzi A, Georgiou K, Guenet B, Hararuk O, Harden JW, Il Y, Hopkins F, Jiang L, Koven C, Jackson RB, Jones CD, Lara MJ, Liang J, McGuire AD, Parton W, Peng C, Randerson JT, Salazar A, Sierra CA, Smith MJ, Tian H, ToddBrown KEO, Déchiré M, van Groenigen KJ, Wang YP, Ouest TO, Wei Y, Wieder WR, Xia J, Xia X, Xiaofeng X, Zhou T (2016) Toward more realistic projections of soil carbon dynamics by earth system models. Glob Biogeochem Cycles 30:40-56. doi:10.1002/ 2015GB005239

Lutfalla S (2015) Persistance à long terme des matières organiques dans les sols: caractérisation chimique et contrôle minéralogique. Thèse de doctorat en Sciences de l'Environnement. Université Paris Saclay

von Lützow M, Kögel-Knabner I, Ludwig B, Matzner E, Flessa H, Ekschmitt K, Guggenberg G, Marschner B, Kalbitz K (2008) Stabilization mechanisms of organic matter in four temperate soils: development and application of a conceptual model. J Plant Nutr Soil Sci 171:111-124. doi:10.1002/jpln.200700047

Machinet GE, Bertrand I, Barriere Y, Chabbert B, Recous S (2011) Impact of plant cell wall network on biodegradation in soil: role of lignin composition and phenolic acids in roots from 16 maize genotypes. Soil Biol Biochem 43:1544-1552. doi:10.1016/j.soilbio. 2011.04.002

Manlay RJ, Freschet GT, Abbadie L, Barbier B, Chotte J-L, Feller C, Leroy M, Serpantié G (2016) Séquestration du C et usage durable des terres en savane ouest-africaine: synergie ou antagonisme? In: Sall S, Bernoux M, Brossard M (Eds.) Carbone des sols d'Afrique et de Madagascar et pratiques de gestion

Manzoni S, Taylor P, Richter A, Porporato A, Agren GI (2012) Environmental and stoichiometric controls on microbial carbonuse efficiency in soils. New Phytol 196:79-91. doi:10.1111/j.14698137.2012.04225.x

Mariani L, Jimenez JJ, Asakawa N, Thomas RJ, Decaens T (2007a) What happens to earthworm casts in the soil? A field study of $\mathrm{C}$ and $\mathrm{N}$ dynamics in neotropical savannahs. Soil Biol Biochem 39:757-767. doi:10.1016/j.soilbio.2006.09.023

Mariani L, Jimenez JJ, Torres EA, Amezquita E, Decaens T (2007b) Rainfall impact effects on ageing casts of a tropical anecic earthworm. Eur J Soil Sci 58:1525-1534. doi:10.1111/j.1365-2389.2007.00960.x

Maron PA, Ranjard L, Mougel C, Lemanceau P (2007) Metaproteomics: a new approach for studying functional microbial ecology. Microb Ecol 53:486-493. doi:10.1007/s00248-006-9196-8
Maron PA, Mougel C, Ranjard L (2011) Soil microbial diversity: spatial overview, driving factors and functional interest. Comptes Rendus de l'Académie des Sciences, Paris, Biologie, Série II 334:403-411. doi:10.1016/j.crvi.2010.12.003

Marschner B, Brodowski S, Dreves A, Gleixner G, Gude A, Grootes PM, Hamer U, Heim A, Jandl G, Ji R, Kaiser K, Kalbitz K, Kramer C, Leinweber P, Rethemeyer J, Schäffer A, Schmidt MWI, Schwark L, Wiesenberg GLB (2008) How relevant is recalcitrance for the stabilization of organic matter in soils? J Plant Nutr Soil Sci 171:91110. doi:10.1002/jpln.200700049

Martens DA (2000) Plant residue biochemistry regulates soil carbon cycling and carbon sequestration. Soil Biol Biochem 32:361-369. doi: 10.1016/S0038-0717(99)00162-5

Martin MP, Wattenbach M, Smith P, Meersmans J, Jolivet C, Boulonne L, Arrouays D (2011) Spatial distribution of soil organic carbon stocks in France. Biogeosciences 8:1053-1065. doi:10.5194/bg-8-1053-2011

Martins MR, Angers DA (2015) Different plant types for different soil ecosystem services. Geoderma 237-238:266-269. doi:10.1016/j. geoderma.2014.09.013

Mathieu JA, Hatté C, Balesdent J, Parent E (2015) Deep soil carbon dynamics are driven more by soil type than by climate: a worldwide meta-analysis of radiocarbon profiles. Glob Chang Biol 21:42784292. doi:10.1111/gcb.13012

McGill WB (1996) In Evaluation of soil organic matter models, eds Powlson DS, Smith P, Smith JU (Springer, Rothamsted), pp 111-132

Meinshausen M, Meinshausen N, Hare W, Raper SC, Frieler K, Knutti R, Frame DJ, Allen MR (2009) Greenhouse-gas emission targets for limiting global warming to $2^{\circ} \mathrm{C}$. Nature 458:1158-1162. doi:10. 1038/nature08017

Mendez-Millan M, Dignac M-F, Rumpel C, Rasse DP, Derenne S (2010) Molecular dynamics of shoot vs. root biomarkers in an agricultural soil estimated by natural abundance ${ }^{13} \mathrm{C}$ labelling. Soil Biol Biochem 42:169-177. doi:10.1016/j.soilbio.2009.10.010

Mendez-Millan M, Dignac M-F, Rumpel C, Rasse DP, Bardoux G, Derenne S (2012) Contribution of maize root derived-C to soil organic carbon throughout an agricultural soil profile assessed by compound-specific ${ }^{13} \mathrm{C}$ analysis. Org Geochem 42:1502-1511. doi:10.1016/j.orggeochem.2011.02.008

Mikutta R, Kleber M, Torn M, Jahn R (2006) Stabilization of soil organic matter: association with minerals or chemical recalcitrance? Biogeochemistry 77:25-56. doi:10.1007/s10533-005-0712-6

Miller AE, Schimel JP, Meixner T, Sickman JO, Melack JM (2005) Episodic rewetting enhances carbon and nitrogen release from chaparral soils. Soil Biol Biochem 37:2195-2204. doi:10.1016/j.soilbio. 2005.03.021

Miltner A, Bombach P, Schmidt-Brucken B, Kastner M (2012) SOM genesis: microbial biomass as a significant source. Biogeochemistry 111:41-55. doi:10.1007/s10533-011-9658-Z

Minasny B, Malone BP, McBratney AB, Angers DA, Arrouays D, Chambers A, Chaplot V, Chen Z-S, Cheng K, Das BS, Fielda DJ, Gimona A, Hedley CB, Hong SY, Mandal B, Marchant BP, Martin M, McConkey BG, Mulder VL, O'Rourke S, Richer-de-Forges AC, Odeh I, Padarian J, Paustian K, Pan G, Poggio L, Savin I, Stolbovoy V, Stockmann U, Sulaeman Y, Tsui C-C, Vågen T-G, van Wesemael B, Winowiecki L (2017) Soil carbon 4 per mille. Geoderma 292:5986. doi:10.1016/j.geoderma.2017.01.002

Monard C, Mchergui C, Nunan N, Martin-Laurent F, Vieublé-Gonod L (2012) Impact of soil matric potential on the fine-scale spatial distribution and activity of specific microbial degrader communities. FEMS Microbiol Ecol 81:673-683. doi:10.1111/j.1574-6941.2012. 01398.x

Monga O, Bousso M, Garnier P, Pot V (2008) 3-D geometrical structures and biological activity: application to soil organic matter microbial decomposition in pore space. Ecol Model 216:291-302. doi:10. 1016/j.ecolmodel.2008.04.015 
Monga O, Garnier P, Pot V, Coucheney E, Nunan N, Otten W, Chenu C (2014) Simulating microbial degradation of organic matter in a simple porous system using the 3-D diffusion-based model MOSAIC. Biogeosciences 11:2201-2209. doi:10.5194/bg-11-2201-2014

Moni C, Derrien D, Hatton PJ, Zeller B, Kleber M (2012) Density fractions versus size separates: does physical fractionation isolate functional soil compartments? Biogeosciences 9:5181-5197. doi:10. 5194/bg-9-5181-2012

Moorhead DL, Sinsabaugh RL (2006) A theoretical model of litter decay and microbial interaction. Ecol Monogr 76:151-174. doi:10.1890/ 0012-9615(2006)076\%5B0151:ATMOLD\%5D2.0.CO;2

Moorhead D, Lashermes G, Recous S, Bertrand I (2014) Interacting microbe and litter quality controls on litter decomposition: a modeling analysis. PLoS One. doi:10.1371/journal.pone.0108769

Mooshammer M, Wanek W, Zechmeister-Boltenstern S, Richter A (2014) Stoichiometric imbalances between terrestrial decomposer communities and their resources: mechanisms and implications of microbial adaptations to their resources. Front Microbiol. doi:10. 3389/fmicb.2014.00022

Mora P, Miambi E, Jimenez JJ, Decaens T, Rouland C (2005) Functional complement of biogenic structures produced by earthworms, termites and ants in the neotropical savannas. Soil Biol Biochem 37: 1043-1048. doi:10.1016/j.soilbio.2004.10.019

Morriën E, Hannula SE, Snoek LB, Helmsing NR, Zweers H, de Hollander M, Soto RL, Bouffaud ML, Buée M, Dimmers W, Duyts H, Geisen S, Girlanda M, Griffiths RI, Jørgensen HB, Jensen J, Plassart P, Redecker D, Schmelz RM, Schmidt O, Thomson BC, Tisserant E, Uroz S, Winding A, Bailey MJ, Bonkowski M, Faber JH, Martin F, Lemanceau P, de Boer W, van Veen JA, van der Putten WH (2017) Soil networks become more connected and take up more carbon as nature restoration progresses. Nat Commun 8:14349. doi:10.1038/ncomms14349

Nagy LG, Riley R, Bergmann PJ, Krizsán K, Martin FM, Grigoriev IV, Cullen D, Hibbett DS (2016) Genetic bases of fungal white rot wood decay predicted by phylogenomic analysis of correlated genephenotype evolution. Mol Biol Evol. doi:10.1093/molbev/msw238

Nannipieri P, Ascher MT, Ceccherini MT, Landi L, Pietramellara G, Renella G (2003) Microbial diversity and soil functions. Eur J Soil Sci 54:655-670. doi:10.1111/ejss.4 12398

Noirot-Cosson PE, Vaudour E, Gilliot J-M, Gabrielle B, Houot S (2016) Modelling the long-term effect of urban waste compost applications on carbon and nitrogen dynamics in temperate cropland. Soil Biol Biochem 94:138-153. doi:10.1016/j.soilbio.2015.11.014

O'Rourke SM, Angers DA, Holden NM, McBratney AB (2015) Soil organic carbon across scales. Glob Chang Biol 21:3561-3574. doi: $10.1111 /$ gcb.12959

Osono T, Takeda H (2006) Fungal decomposition of abies needle and Betula leaf litter. Mycologia 98:172-179. doi:10.3852/mycologia. 98.2.172

Pajor R, Falconer R, Hapca S, Otten W (2010) Modelling and quantifying the effect of heterogeneity in soil physical conditions on fungal growth. Biogeosciences 7:3731-3740. doi:10.5194/bg-7-37312010

Panettieri M, Rumpel C, Dignac M-F, Chabbi A (2017) Does grassland introduction into cropping cycles affect carbon dynamics through changes of allocation of soil organic matter within aggregate fractions? Sci Total Environ 576:251-263. doi:10.1016/j.scitotenv. 2016.10.073

Paradelo R, Virto I, Chenu C (2015) Net effect of liming on soil organic carbon stocks: a review. Agric Ecosyst Environ 202:98-107. doi:10. 1016/j.agee.2015.01.005

Paustian K, Lehmann J, Ogle S, Reay D, Robertson GP, Smith P (2016) Climate-smart soils. Nature 532:49-57. doi:10.1038/nature17174

Pellerin S, Bamière L, Angers D, Béline F, Benoît M, Butault JP, Chenu C, Colnenne-David C, De Cara S, Delame N, Doreau M, Dupraz P, Faverdin P, Garcia-Launay F, Hassouna M, Hénault C, Jeuffroy
MH, Klumpp K, Metay A, Moran D, Recous S, Samson E, Savini I, Pardon L (2013) Quelle contribution de l'agriculture française à la réduction des émissions de gaz à effet de serre? Potentiel d'atténuation et coût de dix actions techniques. Synthèse du rapport d'étude, INRA (France), $92 \mathrm{p}$

Peltre C, Christensen BT, Dragon S, Icard C, Kätterer T, Houot S (2012) RothC simulation of carbon accumulation in soil after repeated application of widely different organic amendments. Soil Biol Biochem 52:49-60. doi:10.1016/j.soilbio.2012.03.023

Perveen N, Barot S, Alvarez G, Klumpp K, Martin R, Rapaport A, Herfurth D, Louault F, Fontaine S (2014) Priming effect and microbial diversity in ecosystem functioning and response to global change: a modeling approach using the SYMPHONY model. Glob Chang Biol 20:1174-1190. doi:10.1111/gcb.12493

Pinheiro M, Garnier P, Beguet J, Martin-Laurent F, Vieublé-Gonod L (2015) The millimetre-scale distribution of 2,4-D and its degraders drives the fate of 2,4-D at the soil core scale. Soil Biol Biochem 88: 90-100. doi:10.1016/j.soilbio.2015.05.008

Plante AF, McGill WB (2002) Soil aggregate dynamics and the retention of organic matter in laboratory-incubated soil with differing simulated tillage frequencies. Soil Tillage Res 66:79-92. doi:10.1016/ S0167-1987(02)00015-6

Plante AF, Fernández JM, Haddix ML, Steinweg JM, Conant RT (2011) Biological, chemical and thermal indices of soil organic matter stability in four grassland soils. Soil Biol Biochem 43:1051-1058. doi: 10.1016/j.soilbio.2011.01.024

Poirier V, Angers DA, Whalen JK (2014) Formation of millimetric-scale aggregates and associated retention of ${ }^{13} \mathrm{C}-{ }^{15} \mathrm{~N}$-labelled residues are greater in subsoil than topsoil. Soil Biol Biochem 75:45-53. doi:10. 1016/j.soilbio.2014.03.020

Poorter H, Jagodzinski AM, Ruiz-Peinado R, Kuyah S, Luo Y, Oleksyn J, Usoltsev VA, Buckley TN, Reich PB, Sack L (2015) How does biomass distribution change with size and differ among species? An analysis for 1200 plant species from five continents. New Phytol 206:1188-1190. doi:10.1111/nph.13571

Pöplau C, Don A, Vesterdal L, Leifeld J, Van Wesemael BAS, Schumacher J, Gensior A (2011) Temporal dynamics of soil organic carbon after land-use change in the temperate zone-carbon response functions as a model approach. Glob Chang Biol 17:2415-2427. doi: $10.1111 / j .1365-2486.2011 .02408$.x

Prieto I, Stokes A, Roumet C (2016) Root functional parameters predict fine root decomposability at the community level. J Ecol 104:725733. doi:10.1111/1365-2745.12537

Qian Y, Follett RF (2002) Assessing soil carbon sequestration in turfgrass systems using long-term soil testing data. Agron J 94:930-935

Ransom B, Kim D, Kastner M, Wainwright S (1998) Organic matter preservation on continental slopes: importance of mineralogy and surface area. Geochimica and Cosmochimica Acta 62:1329-1345. doi:10.1016/S0016-7037(98)00050-7

Rasse DP, Rumpel C, Dignac M-F (2005) Is soil carbon mostly root carbon? Mechanisms for a specific stabilisation. Plant Soil 269: 341-356. doi:10.1007/s11104-004-0907-y

Raynaud X, Nunan N (2014) Spatial ecology of bacteria at the microscale in soil. PLoS One. doi:10.1371/journal.pone.0087217

Remusat L, Hatton PJ, Nico PS, Zeller B, Kleber M, Derrien D (2012) NanoSIMS study of organic matter associated with soil aggregates: advantages, limitations, and combination with STXM. Environ Sci Technol 46:3943-3949. doi:10.1021/es203745k

Rémy JC, Marin-Laflèche A (1974) L'analyse de terre: Réalisation d'un programme d'interprétation automatique. Annales Agronomiques 25:607-632

Resat H, Bailey V, McCue LA, Konopka A (2012) Modeling microbial dynamics in heterogeneous environments: growth on soil carbon sources. Microb Ecol 63:883-897. doi:10.1007/s00248-011-9965-x

Rillig MC, Aguilar-Trigueros CA, Bergmann J, Verbruggen E, Veresoglou SD, Lehmann A (2015) Plant root and mycorrhizal 
fungal traits for understanding soil aggregation. New Phytol 205: 1385-1388. doi:10.1111/nph.13045

Roussel O, Bourmeau E, Walter C (2001) Evaluation du déficit en matière organique des sols français et des besoins potentiels en amendements organiques. Etude et Gestion des Sols 8:65-81

Rovira AD, Greacen EL (1957) The effect of aggregate disruption on the activity of microorganisms in soil. Aust J Agric Res 8:659-673

Ruamps LS, Nunan N, Chenu C (2011) Microbial biogeography at the soil pore scale. Soil Biol Biochem 43:280-286. doi:10.1016/j. soilbio.2010.10.010

Rumpel C, Kögel-Knabner I (2011) Deep soil organic matter - a key but poorly understood component of terrestrial C cycle. Plant Soil 338: 143-158. doi:10.1007/s11104-010-0391-5

Rumpel C, Chabbi A, Nunan N, Dignac M-F (2009) Impact of landuse change on the molecular composition of soil organic matter. J Anal Appl Pyrolysis 85:431-434. doi:10.1016/j.jaap.2008.10.011

Rumpel C, Baumann K, Remusat L, Dignac M-F, Barré P, Deldicque D, Glasser G, Lieberwirth I, Chabbi A (2015) Nanoscale evidence of contrasted processes for root-derived organic matter stabilization by mineral interactions depending on soil depth. Soil Biol Biochem 85: 82-88. doi:10.1016/j.soilbio.2015.02.017

Saenger A, Cécillon L, Sebag D, Brun JJ (2013) Soil organic carbon quantity, chemistry and thermal stability in a mountainous landscape: a rock-Eval pyrolysis survey. Org Geochem 54:101-114. doi:10.1016/j.orggeochem.2012.10.008

Saenger A, Cécillon L, Poulenard P, Bureau F, De Danieli S, Gonzalez JM, Brun JJ (2015) Surveying the carbon pools of mountain soils: a comparison of physical fractionation and rock-Eval pyrolysis. Geoderma 241:279-288. doi:10.1016/j.geoderma.2014.12.001

Saffih-Hdadi K, Mary B (2008) Modeling consequences of straw residues export on soil organic carbon. Soil Biol Biochem 40:594-607. doi: 10.1016/j.soilbio.2007.08.022

Scheu S (2003) Effects of earthworms on plant growth: patterns and perspectives. Pedobiologia 47:846-856. doi:10.1078/0031-405600270

Schimel J (2013) Soil carbon: microbes and global carbon. Nat Clim Chang 3:867-868. doi:10.1038/nclimate2015

Schimel J, Schaeffer SM (2012) Microbial control over carbon cycling in soil. Front Microbiol. doi:10.3389/fmicb.2012.00348

Schimel JP, Weintraub MN (2003) The implications of exoenzyme activity on microbial carbon and nitrogen limitation in soil: a theoretical model. Soil Biol Biochem 35:549-563. doi:10.1016/S00380717(03)00015-4

Schmidt MWI, Torn MS, Abiven S, Dittmar T, Guggenberg G, Janssens IA, Kleber M, Kögel-Knabner I, Lehmann J, Manning M, Nannipieri P, Rasse DP, Weiner S, Trumbore SE (2011) Persistence of soil organic matter as an ecosystem property. Nature 478:49-56. doi:10.1038/nature10386

Shan J, Brune A, Ji R (2010) Selective digestion of the proteinaceous component of humic substances by the geophagous earthworms Metaphire guillelmi and Amynthas corrugatus. Soil Biol Biochem 42:1455-1462. doi:10.1016/j.soilbio.2010.05.008

Simpson AJ, Simpson MJ, Smith E, Kelleher BBP (2007) Microbially derived inputs to soil organic matter: are current estimates too low? Environ Sci Technol 41:8070-8076. doi:10.1021/es071217x

Sistla SA, Rastetter EB, Schimel JP (2014) Responses of a tundra system to warming using SCAMPS: a stoichiometrically coupled, acclimating microbe-plant-soil model. Ecol Monogr 84:151-170. doi:10. $1890 / 12-2119.1$

Six J, Jastrow JD (2002) Organic matter turnover. Encyclopedia of Soil Science, pp:936-942

Six J, Elliott ET, Paustian K, Doran JW (1998) Aggregation and soil organic matter accumulation in cultivated and native grassland soils. Soil Sci Soc Am J 62:1367-1377. doi:10.2136/sssaj1998. 03615995006200050032x
Six J, Elliott ET, Paustian K (2000) Soil macroaggregates turnover and microaggregates formation: a mechanism for $\mathrm{C}$ sequestration under no-tillage agriculture. Soil Biol Biochem 32:2099-2103. doi:10. 1016/S0038-0717(00)00179-6

Six J, Bossuyt H, Degryze S, Denef K (2004) A history of research on the link between (micro)aggregates, soil biota, and soil organic matter dynamics. Soil Tillage Res 79:7-31. doi:10.1016/j.still.2004.03.008

Smith SR (2009) A critical review of the bioavailability and impacts of heavy metals in municipal solid waste composts compared to sewage sludge. Environ Int 35:142-156. doi:10.1016/j.envint.2008.06. 009

Soudzilovskaia NA, Douma JC, Akhmetzhanova AA, van Bodegom PM, Cornwell WK, Moens EJ, Treseder KK, Tibbett M, Wang YP, Cornelissen JHC (2015) Global patterns of plant root colonization intensity by mycorrhizal fungi explained by climate and soil chemistry. Glob Ecol Biogeogr 24:371-382. doi:10.1111/geb.12272

Soussana JF, Tallec T, Blanfort V (2010) Mitigating the greenhouse gas balance of ruminant production systems through carbon sequestration in grasslands. Animal 4:334-350. doi:10.1017/ S1751731109990784

Stamati FE, Nikolaidis NP, Banwart S, Blum WEH (2013) A coupled carbon, aggregation, and structure turnover (CAST) model for topsoils. Geoderma 211-212:51-64. doi:10.1016/j.geoderma.2013.06. 014

Steiner C, Blum WEH, Zech W, de Macedo JLV, Teixeira WG, Lehmann J, Nehls T (2007) Long term effects of manure, charcoal and mineral fertilization on crop production and fertility on a highly weathered central Amazonian upland soil. Plant Soil 291:275-290. doi:10. 1007/s11104-007-9193-9

Stokes A, Atger C, Bengough A, Fourcaud T, Sidle R (2009) Desirable plant root traits for protecting natural and engineered slopes against landslides. Plant Soil 324:1-30. doi:10.1007/s11104-009-0159-y

Strohbach MW, Arnold E, Haase D (2012) The carbon footprint of urban green space - a life cycle approach. Landsc Urban Plan 104:220 229. doi:10.1016/j.landurbplan.2011.10.013

Tardy V, Spor A, Mathieu O, Leveque J, Terrat S, Plassart P, Regnier T, Bardgett RD, van der Putten WH, Roggero PP, Seddaiu G, Bagella S, Lemanceau P, Ranjard L, Maron PA (2015) Shifts in microbial diversity through land use intensity as drivers of carbon mineralization in soil. Soil Biol Biochem 90:204-213. doi:10.1016/j.soilbio. 2015.08.010

Thaer A (1811) Principes raisonnés d'agriculture. Traduit de l'allemand par EVB Crud, JJ Prechoud Ed. Paris, 4 t., pp 1811-1816

Theng BKG (2012) Formation and properties of clay-polymer complexes. Book series: Developments in Clay Science, vol. 4

Thevenot M, Dignac M-F, Rumpel C (2010) Fate of lignins in soil: a review. Soil Biol Biochem 42:1200-1211. doi:10.1016/j.soilbio. 2010.03.017

Tisdall JM, Oades JM (1982) Organic matter and water stable aggregates in soil. Soil Sci 23:821-825

Todd-Brown KEO, Randerson JT, Post WM, Hoffman FM, Tarnocai C, Schuur EAG, Allison SD (2013) Causes of variation in soil carbon simulations from CMIP5 Earth system models and comparison with observations. Biogeosciences 10:1717-1736. doi:10.5194/bg-101717-2013

Torn MS, Trumbore SE, Chadwick OA, Vitousek PM, Hendricks DM (1997) Mineral control of soil organic carbon storage and turnover. Nature 389:170-173. doi:10.1038/38260

Torn MS, Swanston CW, Castanha C, Trumbore SE (2009) Storage and turnover of organic matter in soil. In: Biophysico-chemical processes involving natural nonliving organic matter in environmental systems (Senesi N, Xing B, Huang PM, eds), Chap 6, pp 219-272, John Wiley \& Sons, Inc. doi:10.1002/9780470494950.ch6

Torsvik V, Øvreås L (2002) Microbial diversity and function in soil: from genes to ecosystems. Curr Opin Microbiol 5:240-245. doi:10.1016/ S1369-5274(02)00324-7 
Vidal A, Quenea K, Alexis M, Derenne S (2016) Molecular fate of root and shoot litter on incorporation and decomposition in earthworm casts. Org Geochem 101:1-10. doi:10.1016/j.orggeochem.2016.08. 003

Vieublé Gonod L, Chenu C, Soulas G (2003) Spatial variability of 2,4dichlorophenoxy acetic acid (2,4-D) mineralisation potential at a millimetre scale in soil. Soil Biol Biochem 35:373-382. doi:10. 1016/S0038-0717(02)00287-0

Virto I, Barre P, Burlot A, Chenu C (2012) Carbon input differences as the main factor explaining the variability in soil organic $\mathrm{C}$ storage in notilled compared to inversion tilled agrosystems. Biogeochemistry 108:17-26. doi:10.1007/s10533-011-9600-4

Vogel C, Mueller CW, Höschen C, Buegger F, Heister K, Schulz S, Schloter M, Kögel-Knabner I (2014) Submicron structures provide preferential spots for carbon and nitrogen sequestration in soils. Nat Commun. doi:10.1038/ncomms3947

Vogel L, Makowski D, Garnier P, Vieublé-Gonod L, Raynaud X, Nunan N, Coquet Y, Chenu C, Falconer R, Pot V (2015) Modeling the effect of soil meso- and macropores topology on the biodegradation of a soluble carbon substrate. Adv Water Resour 84:87-102. doi:10. 1016/j.advwatres.2015.05.020

von Lützow M, Kögel-Knabner I, Ludwig B, Matzner E, Flessa H, Ekschmitt K, Guggenberg G, Marschner B, Kalbitz K (2008) Stabilization mechanisms of organic matter in four temperate soils: Development and application of a conceptual model. J Plant Nutr Soil Sci 171:111-124. doi:10.1002/jpln.200700047

Walker AP, Zaehle S, Medlyn BE, De Kauwe MG, Asao S, Hickler T, Norby RJ (2015) Predicting long-term carbon sequestration in response to $\mathrm{CO}_{2}$ enrichment: how and why do current ecosystem models differ? Glob Biogeochem Cycles 5:1-20. doi:10.1002/ 2014GB004995

Wei X, Shao M, Gale W, Li L (2014) Global pattern of soil carbon losses due to the conversion of forests to agricultural land. Scientific Reports. doi:10.1038/srep04062

Wen Y, Li H, Xiao J, Wang C, Shen Q, Ran W, He X, Zhou Q, Yu G (2014) Insights into complexation of dissolved organic matter and $\mathrm{Al}(\mathrm{III})$ and nanominerals formation in soils under contrasting fertilizations using two-dimensional correlation spectroscopy and high resolution-transmission electron microscopy techniques. Chemosphere 111:441-449. doi:10.1016/j.chemosphere.2014.03. 078
Wertz S, Degrange V, Prosser JI, Poly F, Commeaux C, Freitag T, Guillaumaud N, Le Roux X (2006) Maintenance of soil functioning following erosion of microbial diversity. Environ Microbiol 8:21622169. doi:10.1111/j.1462-2920.2006.01098.x

Wertz S, Degrange V, Prosser JI, Poly F, Commeaux C, Guillaumaud N, Le Roux X (2007) Decline of soil microbial diversity does not influence the resistance and resilience of key soil microbial functional groups following a model disturbance. Environ Microbiol 9:22112219. doi:10.1111/j.1462-2920.2007.01335.x

West LT, Hendrix PF, Bruce RR (1991) Micromorphic observation of soil alteration by earthworms. Agric Ecosyst Environ 34:363-370. doi: 10.1016/0167-8809(91)90121-D

Wieder W, Allison SD, Davidson E, Georgiou K, Hararuk O, He YJ, Hopkins F, Luo YQ, Smith MJ, Sulman B, Todd-Brown K, Wang YP, Xia JY, Xu XF (2015) Explicitly representing soil microbial processes in earth system models. Glob Biogeochem Cycles 29: 1782-1800. doi:10.1002/2015GB005188

Winding A, Ronn R, Hendriksen NB (1997) Bacteria and protozoa in soil microhabitats as affected by earthworms. Biol Fertil Soils 24:133140. doi:10.1007/s003740050221

Wu Q-S, Cao M-Q, Zou Y-N, He X-H (2014) Direct and indirect effects of glomalin, mycorrhizal hyphae, and roots on aggregate stability in rhizosphere of trifoliate orange. Scientific Reports. doi:10.1038/ srep05823

Wutzler T, Reichstein M (2008) Colimitation of decomposition by substrate and decomposers - a comparison of model formulations. Biogeosciences 5:749-759. doi:10.5194/bg-5-749-2008

Yue K, Peng Y, Peng C, Yang W, Peng X, Wu F (2016) Stimulation of terrestrial ecosystem carbon storage by nitrogen addition: a metaanalysis. Scientific Reports. doi:10.1038/srep19895

Zhou X, Zhou L, Nie Y, Fu Y, Du Z, Shao J, Zheng Z, Wang X (2016) Similar responses of soil carbon storage to drought and irrigation interrestrial ecosystems but with contrasting mechanisms: a metaanalysis. Agric Ecosyst Environ 228:70-81. doi:10.1016/j.agee. 2016.04.030

Zimmerman AR, Chorover J, Goyne KW, Brantley SL (2004) Protection of mesopore-adsorbed organic matter from enzymatic degradation. Environ Sci Technol 38:4542-4548. doi:10.1021/es035340+

Zimmermann M, Leifeld J, Schmidt MWI, Smith P, Fuhrer J (2007) Measured soil organic matter fractions can be related to pools in the RothC model. Eur J Soil Sci 58:658-667. doi:10.1111/j.13652389.2006.00855.x 